\title{
Lawyers: Gatekeepers of the Sovereign Debt Market?
}

\author{
Michael Bradley ${ }^{a}$, Irving De Lira Salvatierra ${ }^{b}$, Mitu Gulati ${ }^{c}$
}

\begin{abstract}
The claim that lawyers act as gatekeepers or certifiers in financial transactions is widely discussed in the legal literature. There has, however, been little empirical examination of the claim. We test the hypothesis that law firms have replaced investment banks as the gatekeepers of the market for sovereign debt. Our results suggest that hiring outside law firms sends a negative signal to the market regarding the pending issuance; a finding that is inconsistent with the thesis that outside law firms primarily play a certification role in the sovereign debt market.
\end{abstract}

August 28, 2013

Keywords:

Lawyers

Gatekeepers

Reputational Intermediaries

Sovereign Debt

${ }^{a}$ Duke University, Fuqua School of Business \& School of Law

${ }^{\mathrm{b}}$ Duke University, Economics Department

${ }^{\mathrm{c}}$ Duke University, School of Law

*Corresponding author Irving De Lira Salvatierra; iad4@duke.edu. 


\section{Introduction}

The dominant view in legal scholarship is that transactional lawyers add value by serving as reputational intermediaries. The notion is that a key function of an elite law firm -- like the function of an elite investment bank or accounting firm -- is to "rent" its reputation to a pending transaction [40]. While this is a widely accepted thesis, the question is how much value do they create? No one seriously disputes that lawyers also do a lot of other more traditionally lawyerly things like helping with regulatory compliance, drafting contracts, finding tax loopholes and so on. No one also disputes that other institutions such as investment banks and accounting firms also serve as reputational intermediaries on many of the same transactions. But can we determine, as an empirical matter, whether the role that lawyers play as reputational intermediaries is a central one (as many in the legal literature suggest) or a marginal one (as some skeptics argue)?

The classic work on lawyers as reputational intermediaries is a 1984 paper by Ronald Gilson [40]. Gilson posits that transactional lawyers help reduce transactions costs. He observes that they do things like advise clients about future contingencies, identify differences in valuations among parties and generally help deals get done. ${ }^{1}$ The key element of Gilson's thesis regarding the value added by lawyers, however, has to do with information costs. The big law firms that specialize in transactional work (M\&A, private equity, debt issuances, public offerings, and so on) play the role of reputational intermediaries or, as it is often referred to, "gatekeepers".

Gilson's reputational intermediary story has generated a significant amount of debate. $^{2}$ The basic argument is that most large financial transactions involve significant asymmetric information or verification problems among the various players (investors, issuers, bankers, regulators, etc.). Because the parties involved in these transactions are generally not repeat "transactors", they cannot help solve these problems by credibly asserting that their own reputations are at stake. Counterparties are going to be concerned about the incentives to overstate the value of any transaction. ${ }^{3}$ The large, modern law

\footnotetext{
${ }^{1}$ E.g., Gardner [36], Gilson and Mnookin [41].

${ }^{2}$ E.g., Barnett [4],[5], Dent [21], Kim [46], Carney, Dent and Gilson [16], Wilkins [63].

${ }^{3}$ See Gilson [40], Okamoto [52], Bainbridge [3].
} 
firms, however, are institutions that have built up reputations over decades, whilst serving a wide range of clients. They are repeat transactors, which gives them the ability to help solve information/verification problems by acting as intermediaries and lending their reputation to the transaction. ${ }^{4}$

The puzzle though is that there is nothing lawyerly about this function. Investment bankers and accountants also work in firms that are repeat transactors. Indeed, bankers and accountants often have more money at stake if their reputations are tarnished - witness the case of Arthur Anderson's demise in the wake of the Enron debacle. ${ }^{5}$ And these institutions should be, in theory, able to perform at least the same reputational intermediary role being posited for law firms. Critics of the Gilson thesis, making this point and others, have questioned the extent to which the reputational bonding role of lawyers is significant. ${ }^{6}$

The theoretical literature has generated at least three unanswered empirical questions. First, how plausible is the reputational intermediary model for lawyers? Second, to the extent that the Gilson model is plausible, can we quantify how much value lawyers add in their role as reputational intermediaries? Third, how has the role of lawyers as reputational intermediaries evolved over time? We believe that our empirical analyses shed light on these questions.

The remainder of the paper is organized as follows. Section 2 provides the general context of the sovereign debt market and the related literature to reputational intermediaries. Section 3 describes our database. Section 4 presents our main results about lawyers as reputational intermediaries. Section 5 concludes.

\section{Background and Context}

\subsection{The Sovereign Debt Market}

We analyze the role of transactional lawyers through the lens of the market for sovereign debt. The basic characteristics of the sovereign debt market suggest that it should be a good area in which to test the lawyers-as-gatekeeper thesis. Sovereign issuers face three key problems. First, there is an asymmetric information problem. The finances of sovereigns tend to be opaque in the best of circumstances - the recent woes of the

\footnotetext{
${ }^{4}$ Ribstein [54].

${ }^{5}$ E.g., Rauterkus and Song [53].

${ }^{6}$ E.g., Schwarcz [58], Lipshaw [48], Ribstein [54].
} 
Euro area provide an illustration of this. ${ }^{7}$ In addition, the primary asset of a sovereign is the willingness of its citizens to pay taxes - a difficult matter to predict. Foreign investors are at a particular disadvantage in terms of being able to observe the sovereign's finances or predict the future preferences of its voters.

Second, sovereigns are difficult to sue, and even more difficult to enforce contractual agreements against. Even with explicit waivers of sovereign immunity, finding assets to serve as collateral or repayment is an onerous task.

Third, while sovereigns are, in theory, infinitely lived entities, their agents (politicians and bureaucrats) are not. The primary goal of most politicians is to win elections, which necessarily gives them a short-term focus.

Reputational intermediaries could solve the foregoing problems. But they would have to: (1) demonstrate themselves as having the skill and ability to evaluate the complex and opaque information about the sovereign; and (2) be able to credibly show that they would have much to lose if their representations regarding a sovereign and a pending issue turned out to be incorrect. In theory, both investment banks and law firms that ply their trade in the sovereign debt market have the abilities and incentives described above.

Further, the sovereign debt area is one in which alternate explanations for what transactional lawyers do may be of limited importance - at least in comparison to domestic corporate issuances in the U.S. For example, consider three primary competitors of the reputational intermediary story where lawyers add value in terms of: (1) helping clients negotiate regulatory barriers; (2) performing due diligence in anticipating future contingencies and making sure that the terms of the debt contracts protect against things going wrong; and (3) assisting the client in dealing with legal claims. At first cut, none of these explanations seems to have much promise. First, there are few regulations governing the issuance of sovereign debt. Second, in terms of the effort that might be exerted in drafting and revising contracts, most of the documents are boilerplate. Third, in terms of lawyers providing protection against legal claims,

\footnotetext{
${ }^{7}$ The problem of opacity in sovereign finances has received attention recently, thanks to the crisis in the euro area. Academic papers have documented a wide range of accounting devices that have been used by sovereign issuers to try and mislead both regulators and the markets. E.g., Buti, Martins and Turrini [15], Dias, Richmond and Wright [23], Buchheit and Gulati [14], Irwin [43].
} 
sovereign debtors are relatively immune against lawsuits; after all, they are sovereigns. Given the foregoing, the reputational-intermediary story is a plausible explanation for the functions of lawyers in this market. ${ }^{8}$

We test the implications of this theory using an extensive dataset of sovereign bonds covering almost 200 years. In constructing this database we encountered numerous limitations due in part to the lack of regulatory requirements mandating very much disclosure on the part of issuers. In particular, we do not have information on how much individual law firms were compensated on specific transactions. The absence of information on the price of a product as vague as "reputational intermediary" makes it difficult to evaluate the quality of the product. Consequently, even if we are able to determine that it is likely that law firms are serving as reputational intermediaries in this market, the lack of information on how much they are charging makes it difficult to draw conclusions of how important this role is. Nevertheless, we believe that the empirical analysis that follows takes some steps towards tackling this and related issues.

\subsection{Literature}

There is a considerable literature examining the effects of intermediaries in providing credibility enhancements for products across a number of markets ${ }^{9}$ Intermediaries do sometimes appear to play a role in adding credibility. ${ }^{10}$

Economics and finance scholars studying the reputational intermediary question generally assume that the reputation that underwriters bring to an issue is the primary mechanism for solving the asymmetric information problem. ${ }^{11}$ This construct has led to an extensive literature relating the reputation of investment bankers to the cost of capital. ${ }^{12}$ The evidence shows that investment banks with high reputations are associated with high quality, low-risk issuances and higher banker fees. The evidence also shows that investors are willing to pay a premium for certification of the quality of an issue, as investors interpret an agreement with a reputable underwriter as a positive signal

\footnotetext{
${ }^{8}$ See also Buchheit [13].

${ }^{9}$ Generally, see Klein [47], Jin, Kato and List [45].

${ }^{10}$ E.g., Gatti, Kleimeier, Megginson and Steffanoni [37], Riley [56].

${ }^{11}$ See Milgrom and Roberts [51], Shapiro [59], Diamond [22].

12 See Chemmanur and Fulghieri [18].
} 
regarding the quality of the issue. ${ }^{13}$ Thus, reputable and larger investment banks appear to be associated with higher quality issues, lower yields and higher fees. ${ }^{14}$

Only a handful of studies have examined the impact of lawyers on the cost of capital and the majority of these studies focus exclusively on corporate issuances. To the extent that lawyer reputation matters in reducing the cost of capital, the relevant reputation is that of the underwriter's counsel. ${ }^{15}$ The reputation of the issuer's counsel does not appear to reduce capital costs and may even increase them. ${ }^{16}$

In the context of the sovereign debt market, the most relevant work has been by Marc Flandreau and a series of coauthors [28] [29] [30] [31] [32]. ${ }^{17}$ They find that in the nineteenth and early twentieth centuries, underwriters performed a gatekeeping role in the sovereign debt market. Banking houses such as the Rothschilds and Barings would commit to monitoring borrowers and ensure that these borrowers behaved themselves vis-à-vis investors. ${ }^{18}$ Over long periods of time, these banks developed close relationships with particular sovereign debtors. An example is the relationship between the Rothschilds and Brazil; one that survived the Brazilian government transitioning through a variety of types of governments including a monarchy, a military dictatorship and a democracy. ${ }^{19}$ It should be noted that Brazil as well as other Rothschild's clients were of the highest quality. ${ }^{20}$ Investors might not be able to obtain good information about a sovereign's financial condition, but they could rely on the historical performance of the bank that was underwriting the issue. Quantitatively, the Flandreau et al. studies find a strong relationship between sovereign bond defaults and underwriter reputation in the 1800s and early 1900s. However this relation disappears in the post-World War II era. ${ }^{21}$

\section{Data}

\footnotetext{
${ }^{13}$ See Fang [24].

${ }^{14}$ See James [44], Carter, Dark and Sing [17], Fang [24], Livingston and Miller [49].

${ }^{15}$ See Barondes, Nyce and Sanger [6], Beatty and Welch [8], Fang [24] .

${ }^{16}$ See Fang [24].

${ }^{17}$ See Chemmanur and Fulghieri [18]. See also Flores [33].

${ }^{18}$ Flandreau and Flores [28].

${ }^{19}$ For a historical treatment of the Rothschilds, see Ferguson [25] [26].

${ }^{20}$ See Flandreau Flores [28].

${ }^{21}$ See, e.g., Flores [33].
} 
Our dataset covers roughly a two hundred year period, from 1823 to 2012 . In constructing our dataset we drew on a variety of sources. For the entire period, we have 2,091 sovereign bond contracts issued by 128 sovereigns.

We divide the dataset into two separate sub-periods, depending on the source of the data and how they were collected. The first sub-period is from 1820 to 1945 . In most cases, our sources for these data are the copies of the physical bearer bonds themselves. These bonds are not the actual contracts, but typically report the key contract terms to prospective purchasers of the instrument. For this pre-World War II period, there is no single source of sovereign bonds that comes close to being comprehensive. We constructed our dataset for this period from roughly a dozen museums, archives and libraries. $^{22}$ We then supplemented these materials from information in newspapers advertisements and discussions in investor reports at the time. From these various sources, we have information on roughly 600 bonds from the pre-World War II period. There are gaps in the data; we have only a few offerings from the Amsterdam market of the early 1800s, and it is likely that we are missing a number of bonds that were issued on the Paris market. Nevertheless, we have one of the most comprehensive datasets on sovereign bond contract terms for the period in question.

For the post-World War II period, public databases provide fairly comprehensive data on sovereign bonds, particularly for the years 1980-2011. We accessed two databases for our post-World War II data: Thomson One Banker and Perfect Information. Our sources for this period are the prospectuses and offering circulars that were filed with the relevant exchanges or regulatory authorities. These sales documents typically report on the key contract terms of the bond contract. Both the Thomson and Perfect Information databases are incomplete in terms of the data they report on bonds issued between 1945 and 1980. We were able to supplement the data for this period somewhat, however, from information available from the sources mentioned above. In sum, we have a sample of 1,479 bonds, issued by 104 sovereigns over the years 1946-2012.

\footnotetext{
${ }^{22}$ The archives include: Rothschilds, Barings, UBS, HSBC, Guildhall, the Library of Congress, the British Library, the Morgan Library, the Harvard Business School, Yale University, Cornell University, Duke University, Columbia University and Wertpapierwelt.
} 
For each bond, we obtained the actual bond and/or the relevant sales documents and coded nine parameters: issuer, issue date, maturity date, interest rate $\underline{a t}$ issuance,${ }^{23}$ governing law, lead underwriter, number of underwriters in the syndicate, issuer's counsel, and underwriter's counsel. From other public data, we obtained the rating of each issuance. Bond ratings are not available for the full pre-World War II period. However, as we demonstrate below, ratings are very relevant for the post-World War II period. For that period, we rely on the bond ratings from S\&P. Where ratings from S\&P are not available, we use a rating by one of its competitors (Moody's or Fitch) and convert those ratings into their equivalent on the S\&P scale.

In total, there are approximately 128 issuers and 2,091 issues in our dataset. Our sample varies from issuers who have conducted hundreds of offerings (e.g., Argentina) to those that have done one or two (e.g., Namibia or Ghana). Table 1 presents the top 50 issuers in our sample and the number and timing of their issuances. All of these are bonds were issued in international markets, suggesting that the buyers were primarily foreign investors. Almost none of the bonds were issued in domestic currencies.

[Insert Table 1]

\section{Testing for Lawyers as Reputational Intermediaries}

\subsection{The Basic Transactional Context}

Lawyers do not necessarily have an important role to play in a sovereign debt issuance. The requirements in terms of mandatory disclosures and regulatory filings tend to be simple, given that these are sovereign issuers who are assumed to be relatively safe for the most part. The two primary participants in a sovereign issuance are the issuer and the underwriter. ${ }^{24}$ Given the size and sophistication of the types of sovereigns and underwriters who participate in this market, it is safe to assume that both sets of entities will tend to have in-house counsel. In other words, sovereign issuances could probably be done without the need to hire outside lawyers, which is the case for the largest and most reputable issuers such as Germany and the United States. Less reputable sovereigns and

\footnotetext{
${ }^{23}$ Our analysis focuses on the when-issued rate since these bonds rarely trade and market prices are unavailable. See Section 5 for a further justification for using when-issued rates.

${ }^{24}$ Throughout this article, we use the terms underwriters and investment bankers interchangeably.
} 
underwriters, who do hire outside counsel, are possibly incurring expenses that they could avoid. ${ }^{25}$ This is particularly so since the law firms that tend to work in this market are among the most elite (and, therefore, most expensive) in New York and London. According to the reputational intermediary theory, these expenditures are paid to outside lawyers because they lend their names, prestige and reputations to certify the quality of an issue.

In theory, both the issuer and underwriter can avail themselves of outside counsel. The data show that there are a handful of instances in which the issuer is represented by an external law firm and the underwriter is not. There are many cases in which the underwriter is represented by outside counsel but the issuer is not. Finally, we have a large number of cases in which both parties are represented by outside counsel.

Before we continue, we pause to note an important fact concerning the hiring of outside counsel in these transactions. For the roughly 1,500 issuances written under New York and English laws in the post-war era, the major portion of the deals have at least one outside law firm working on the transaction. The two primary categories of deals are those where both the issuer and the underwriters have separate outside counsel (618 deals) and those where only the underwriter has outside counsel (612 deals). These data suggest that there is a large fraction of deals where the issuer foregoes using outside counsel and only the underwriter hires an outside firm. However, this conclusion ignores a peculiar aspect of the sovereign debt market. In this market, the issuer either hires one set of outside lawyers for the deal or hires two sets of outside lawyers - one for themselves and one for the investment bank. In other words, while as a formal matter, the name of the underwriter's counsel is featured on the issuing materials, these tend to be what are called "designated underwriter's counsel". This means that the issuer chooses the outside law firm that it wishes to work with the underwriter. Thus the lawyer selection process begins with the issuing sovereign choosing an investment bank to underwrite the deal. The next decision for the sovereign is whether to hire an outside law firm to work with the chosen underwriter. If no underwriter's counsel is chosen, we classify this as a zero-lawyer transaction. If the issuer selects an outside law firm to work

\footnotetext{
${ }^{25}$ We assume that using outside counsel is more expensive than just relying on in-house counsel to do the work.
} 
with the investment bank, then we designate this law firm the underwriter counsel and classify the transaction as a one-lawyer deal. Finally, if the issuer designates both an UC and a second outside firm to oversee the transaction, we designate the second law firm as issuer counsel and classify the transaction as a two-lawyer transaction. ${ }^{26}$

As we show below, the underwriters for any given sovereign's issuances frequently change. However, the counsel for the underwriter's side generally remains the same (after all, they are chosen by the issuer). The explanation given for this practice is that to be effective, the counsel for the underwriters need to have a good understanding of the sovereign's financial and political condition, and it would be too expensive to have new lawyers try to learn the complexities of a sovereign's situation every time an issuance is done, particularly for a sovereign doing frequent issuances. ${ }^{27}$ To reiterate, in deals that have two sets of outside counsel, one for the issuer's side and one for the underwriter's side, it is the issuer who hires both firms and stipulates a particular role for each.

Information on how much outside lawyers are compensated is difficult to obtain. However, based on informal discussions with lawyers who work on these deals, it seems

\footnotetext{
${ }^{26}$ We have only a few observations in which the issuing sovereign identifies an outside counsel for itself but does not hire a law firm to work with the investment bank.

${ }^{27}$ Unsurprisingly, the practice of the issuer selecting and paying for the counsel on the underwriter side has raised conflict of interest issues. The explanation given in the text is from the New York State Bar Ethics. In relevant part, the report explains:

The appointment of a Designated Underwriters' Counsel is thought to benefit the frequent issuer, underwriters and investors. Because such counsel works consistently on offerings of the issuer's securities, it becomes particularly familiar with the issuer, and thereby better able to make judgments about the information that should be disclosed in offering documents. This familiarity may therefore improve the quality of disclosure in offering documents, lower transaction costs and promote the efficiency of the capital markets by allowing seasoned issuers to reach the capital markets quickly, as market and other opportunities arise. The ability to reach the capital markets quickly and opportunistically is particularly important in the context of so-called "shelf" offerings. In addition, having a single law firm as underwriters' counsel for frequent issuers rather than different firms chosen by the lead underwriter for different offerings gives the issuer the benefit of underwriter's counsel more familiar with the issuer's business and able to update its knowledge more quickly and cost effectively.
}

See New York State Bar Association Committee on Professional Ethics, Conflicts of Interest: Designated Underwriter's Counsel, Opinion \# 818, November 28, 2008 (citation omitted), available at http://www.nysba.org/AM/Template.cfm?Section=Ethics_Opinions\&template=/CM/ContentDisplay.cfm\& ContentID=55866. On this matter, see also Municipal Securities Rulemaking Board Notice, Issuer Selection Of Underwriters' Counsel, September 3 1998, available at http://www.msrb.org/MSRB1/reports/0299v191/ucounsel.htm; Comment Letter from New York State Bar Association on Implementation of Standards for Professional Conduct for Lawyers, December 18, 2002, available at http://www.sec.gov/rules/proposed/s74502/gesbackman1.htm\#P73_26356. 
safe to say that hiring two elite law firms as outside counsel is the most expensive way to do one of these transactions. Two factors produce higher costs. First, two law firms are involved. Even if they divide the work on the deal, there would be greater transactions costs than if the deal were done by just one firm. But, second, the two law firms do not typically divide up the work. Instead, they stand in opposition to each other, protecting different sets of interests - those of the issuer and those of the underwriter. More lawyers means more friction, more billable hours and, ultimately, higher costs.

Our working hypothesis is that there are significant information asymmetries between issuers and investors in the sovereign debt market. Economists who have examined the asymmetric information problem have focused on investment banks and rating agencies as serving as reputational intermediaries. ${ }^{28}$ Gilson's thesis suggests that lawyers might also play a role.

We propose five analyses that address the following three questions: (1) do lawyers serve as reputational intermediaries; (2) if they do, how much value do they add in this role; and (3) has their role changed over time. Each of the five analyses defined below is imperfect. Together, however, they shed some light on the questions raised above.

Our dataset covers fifteen different legal systems over a span of roughly two hundred years. We begin our analysis by demonstrating that lawyers in the $19^{\text {th }}$ and early $20^{\text {th }}$ century had little to nothing to do in the sovereign bond market. As discussed above, the evidence presented by Flandreau et al. shows that the role of gatekeeper in this period was filled by investment bankers. However, as we show below, there was a sea change in the two institutions after World War II, and especially after 1980. Thus, we begin our analysis by isolating the time period in which the reputational intermediary hypothesis is implausible. The subsequent analyses then focus on the subsets of the data in which the hypothesis is plausible.

\subsection{The Analyses}

\subsubsection{Names on Documents}

\footnotetext{
${ }^{28}$ See Flandreau, Flores, Gaillard and Nieto-Parra [30], Flandreau and Flores [28] [29].
} 
In this section, we examine if and when sovereign issuers began advertising the identities of their lawyers to their investors. If sovereigns are not touting the lawyers who worked on the issuance, then it is unlikely that the lawyers are serving any sort of signaling function. In other words, if we do not find the lawyers being advertised, we can reject the reputational intermediary story out of hand. ${ }^{29}$

Based on our time series of issuances, there appears to be a difference in the role of lawyers before and after World War II. Lawyers do not appear to have played a reputational intermediary role in the pre-World War II data (1823-1945). Of the 614 issuances from the pre-war period, the identities of the lawyers are mentioned only 16 times and five of those are for the same issuer, Germany. Thus, law firms are mentioned in only 2.61 percent of the issues in our pre-war subset. Perhaps more telling, when lawyers are mentioned during this period, there is usually an explicit explanation for mentioning them in the offering materials. In 12 out of the 16 instances where lawyers were mentioned, the lawyers were mentioned simply to tell investors that, if they wished to examine background documents, those materials would be available at the offices of the named lawyers. This is in contrast to the manner in which lawyers are mentioned in the post-World War II data, where their names are frequently mentioned prominently on the back cover of the sales documents as having worked on the deal.

The marginal role that lawyers played in the pre-war period is illustrated in the first sovereign bond that we found that mentions lawyers. This bond was issued by the Confederate States of America in 1863 and is known as the Cotton Bond. The bonds carried a 7 percent interest rate and matured when all hostilities had ceased. The bonds were convertible into cotton at $\$ 12$ per bale. At the time of issuance, cotton was selling for twice that amount, thanks mostly to the Union blockade, and was steadily on the rise. Although it was sold at a discount (30 percent), the issue was oversubscribed.

Disputes over the quality of the cotton to be delivered at maturity were anticipated. The bonds had an arbitration provision that allowed for disputes over cotton quality to be adjudicated by an arbitral panel. After describing the arbitral panel, one

\footnotetext{
${ }^{29}$ The fact that the identity of lawyers is being advertised in the issuance documents does not, by itself, mean that the issuers are renting the reputations of the lawyers. It may, for example, be that the lawyers are trying to advertise themselves. We cannot disprove that possibility. Our point though is that the absence of any mention of the lawyers on the deal indicates that they are probably not adding reputational value.
} 
member to be appointed by each side and an umpire to be appointed thereafter, the bond then names the lawyers who will handle the administrative matters; the firm of London solicitors, Messrs. Freshfields and Newman. ${ }^{30}$ Freshfields \& Newman was a pre-eminent law firm, having represented the Bank of England since the mid 1700s. ${ }^{31}$ From the language in the bond, it is clear that the only reason that the lawyers are mentioned is to invite investors to visit the firm if they would like to examine a certified copy of the Act of Congress that approved the conditions of the bond. Figure 1 is a reproduction of the bond. As an aside, another eminent London law firm was also involved in the deal, Crowder, Maynard, Son \& Lawford, and it was not mentioned at all. ${ }^{32}$ By contrast, the bankers, Emile Erlanger \& Co. and J. Henry Schroeder \& Co have their names prominently displayed both on the sides of the bonds and at the bottom.

\section{[Insert Figure 1]}

Starting in late 1946, immediately after the war, the names of law firms began to appear in the sales documents as a regular matter, and independent of any administrative or legal function that they might be performing. Indeed it is not until 1956 that we find the first post-war sovereign issuance where outside counsel is not mentioned. There have been a number of changes or shocks to the sovereign debt market that might explain the enhanced role of lawyers in the post-war era. First, the depression that preceded World War II produced perhaps the biggest crisis that the sovereign debt market will ever see, with roughly 40 percent of sovereign issuers defaulting over the period 1929-1937. ${ }^{33}$ Second, in the wake of World War II, the global financial system was significantly altered with the establishment of the Bretton Woods Agreement and its attendant institutions.

The bulk of the sovereign bonds in our sample $(82.4 \%)$ in the post-World War II era were issued under either New York or English law. (See Figure 2 and Table 2.) Of the

\footnotetext{
${ }^{30}$ See 7 Per Cent Cotton Loan, Confederate States of America, 1863.

${ }^{31}$ See Bennett [9].

${ }^{32}$ Almost none of the innumerable discussions of the civil war financing mentions the lawyers, let alone any reputational role they may have played. E.g., Foote [34], Weidenmier [62], Gentry [39].

${ }^{33}$ See Flandreau, Gaillard and Panizza [32]. While there was an initial impetus towards SEC regulation of sovereign issuances in the U.S. in the wake of the many sovereign defaults during the depression, this waned in the post-World War II era. See Batlan [7].
} 
remaining, the majority were issued under German law (8.5 percent of the total sample), with fewer issued under Austrian, Swiss, Luxembourg, French, Spanish, Dutch, Portuguese, Japanese, and Italian laws. Many nations also issue bonds that are governed by local law and are primarily sold to domestic investors. However, the asymmetric information problems with bonds written under local law are likely minimal. Citizens have the power to vote their governments out of office and also probably have better information. Therefore, we do not include bonds written under local law in our dataset.

\section{[Insert Table 2]}

Figure 3 and Table 2 show the number of bonds issued under each of the different types of laws that explicitly mention lawyers. Note the difference between the two highvolume jurisdictions (New York law and English law) and the other jurisdictions. In almost all of our bonds governed by English and New York law (over 97 percent), the identities of one or both of the law firms are mentioned prominently in the offering materials. In contrast, in the majority of the small jurisdiction issuances, such as those under German, French, or Luxembourg law (over 85 percent), the identities of the lawyers are not mentioned.

\section{[Insert Figure 2 and Figure 3]}

These data suggest that to the extent lawyers are operating as reputational intermediaries, they do so primarily in the two largest markets, New York and London, and only in the post-war period. In the smaller markets, advertising the identities of the lawyers is perhaps viewed as adding less value. We have been given at least three explanations from practitioners for the "no lawyer mentioned" phenomenon in the smaller markets. First, it may be that these markets are more heavily regulated than either New York or London and investors therefore do not need additional certification. Second, perhaps the small size of these markets means that there are no more than a handful of firms who could work on large cross-border financial transactions, thereby obviating the need for disclosure of their identities. Third, it may be that the only issuers 
tapping these smaller markets are either the higher rated issuers or those with close ties to the national markets in which they are issuing. Consequently, defaults against the investors in these jurisdictions are unlikely.

In sum, the data from the post-war period suggest two conclusions. First, that the reputational intermediary story, to the extent it holds, is most plausible in the modern era. Second, even in the modern era, there is variation across jurisdictions. The reputational story may hold in the New York and London markets, where the identities of the lawyers are prominently signaled in the sales materials. But it is less plausible in the other, smaller, markets, such as Frankfurt and Paris.

\subsubsection{Long-Term Relationships}

Our second set of analyses is based on the definition of a reputational intermediary. In our view, a reputational intermediary is an entity that helps solve the asymmetric information problem between issuers and investors. The basic problem is that information about a complex entity such as a sovereign is hard to observe. The incentives of the sovereign debtor to maintain its reputation do not fully solve this problem because of an inherent agency conflict. The governments (the agents who run the sovereigns) are typically short-term players and, therefore, investors have reason to be suspicious about their claims. This problem can be solved, however, if the sovereign issuer hires an intermediary who can certify the sovereign's information; that is, an intermediary who itself has a reputation to maintain. Investment banks and law firms, it has been suggested, are among the institutions that can perform this role. In order to perform this role, they presumably have developed long-term relationships with the sovereign issuers. There are at least two reasons for this. First, their long-term relationships help them acquire specialized information about sovereigns. ${ }^{34}$ Second, to the extent that their access to future employment depends on their performance vis-à-vis investors on prior deals, they have an incentive to ensure that their sovereign clients provide accurate disclosures and representations.

Based on the foregoing, we examine the data on law firms and investment banks with respect to the length of their relationships with issuers. We construct a simple measure of the rate at which sovereign issuers change their bankers or lawyers from deal

\footnotetext{
${ }^{34}$ See Buchheit [13].
} 
to deal. If a sovereign changes these agents from deal to deal, then there is obviously no long-term relationship. If, on the other hand, issuers hire the same law firm or investment bank on every deal, then there is reason to believe that these entities have access to privileged information and are in a position to certify the quality of the issue.

For each issuance by a sovereign, we count the number of times its lawyers or underwriters change from the prior deal. If there is a change, we count that as a 1 and if there is no change from one deal to the next, we count that as a 0 . Over a given time period and set of deals, therefore, we have estimates of the rates at which sovereigns change the various intermediaries who work on their deals. Typically, there are two sets of lead lawyers on any deal (issuer's counsel and underwriter's counsel) and one set of lead bankers (the managing underwriter). We consider the relationships between bankers and issuers first.

As described previously, there are almost no deals in which lawyers were used in the pre-World War II period. Hence, there is nothing to measure in this time period regarding law firms. However, we can examine the extent of the relationships between issuers and investment banks in the pre and post-World War II periods. Figures 4 and 5 illustrate the comparative numbers. In Figures 6 and 7, we separate the sovereign issuances according to the legal jurisdictions under which they were written. As seen in these figures, there is a difference between the issuer-bank relationships in the pre- and post-war periods. In the pre-war period, issuers tended to stay with the same banks. This finding is consistent with the research by economic historians on firms such as the Rothschilds, Barings, Credit Lyonnais and Paribas, who tended to have strong relationships with their sovereign clients. In the post-war period, however, the issuerbank relationships became significantly weaker. As Figure 5 shows, this is particularly so, beginning around 1980 through 2012. Until around the 1978-1982 period, we see relatively long lasting investment bank-issuer relationships. This is evidenced by the smaller number of changes in investment bankers per deal done as compared to the post1982 period. ${ }^{35}$ In other words, issuers tend to use the same underwriters over and over, until around 1980-1982, after which the duration of banker-issuer relationships shortens.

\footnotetext{
${ }^{35} \mathrm{We}$ calculate the number of changes in bankers divided by the number of opportunities for change. The denominator is the number of deals minus 1 (the number of opportunities for change).
} 
[Insert Figure 4 and Figure 5]

[Insert Figure 6 and Figure 7]

The Latin American debt crisis may provide an explanation for this change. The crisis hit the hardest in the early 1980s. One of the problems that the crisis revealed was that a number of western banks had become severely overexposed to particular Latin American countries. Significant pressure was then brought by regulators on the banks to induce them to diversify their portfolios. ${ }^{36}$ What the data might be showing, therefore, is a manifestation of those pressures - with the financial institutions getting out of the business of building long-term relationships with sovereign issuers and lawyers filling the void.

Table 3 reports the Z-statistics of the Wilcoxon-Mann-Whitney test that confirm the suggestion from Figures 4 and 5. Table 3 reports the comparative numbers using two different break points. First, it reports the comparison in terms of the pre and post-war data (1946 being the break point) and then reports the comparison in terms of the pre and post-Latin American debt crisis (1982 being the break point). Between 1946 and 1982 little activity took place in the sovereign bond markets (Flandreau et al. call it the "sleeping beauty" period of the sovereign bond markets), so the two sets of comparisons show similar results. ${ }^{37}$ For each of the comparisons in Table 3, we report two different specifications. In the first specification, we simply compare the numbers of deals before and after our specified break points. The results confirm the visual impression given in Figures 4 and 5 that investment bankers changed more often in the past (whether we look at pre 1946 or pre 1982) than in the modern era. In the second specification, we separate the deals in terms of the markets in which they were executed. Starting in roughly the early 1900s, many sovereign issuers began issuing in multiple markets. Previously sovereigns tended to issue bonds in only one jurisdiction. For those issuances, it was

\footnotetext{
${ }^{36}$ On the Latin American debt crisis of the late 1970s and early 1980s, see Cline [19].

${ }^{37}$ The Wilcoxon-Mann-Whitney test is a nonparametric test that measures if two groups come from the same distribution. In this case the results suggest that there is a statistically significant difference between the pre and post-World War II distributions of long-term relationships between issuers and underwriters.
} 
sometimes the case that they would have to hire different investment banks for the separate jurisdictions. This was particularly so if their primary banker did not have operations in multiple jurisdictions. The Confederate bond we examined earlier is an example of this - the Confederacy used Emile Erlanger \& Co. in Paris for an issuance in francs and J. Henry Schroeder in London for an issuance in pounds sterling. Since the pre-war contracts did not specify governing laws, we separate the data by currency of issuance. The results are consistent with the first specification, albeit stronger. Consistent with the work of Flandreau et al., the data indicate a shift from a market where underwriters served as reputational intermediaries (the pre-war market and extending to the end of the 1970s) to one where they did not (the era starting in about 1982). ${ }^{38}$

\section{[Insert Table 3]}

Flandreau et al. follow their observation regarding the disappearance of investment bankers as reputational intermediaries in the modern era by asking the question "what types of entities substituted for investment banks;" after all, the asymmetric information problem didn't disappear at the end of this time period. They suggest that rating agencies may have filled the void. ${ }^{39}$ That may be a partial explanation. The question we are asking is whether law firms may have also emerged as substitutes for the bankers in playing the reputational intermediary role.

\section{[Insert Figure 8 and Figure 9]}

Figures 8 and 9 show the rate of change for issuer's and underwriter's counsel, respectively, in the post-war period. The strength of the relationships between lawyers and issuers in comparison to the relatively weak relationships between bankers and issuers during this same period is striking (See Table 4 and 5). The data show the lawyers who work on a sovereign's debt issuances rarely change.

\footnotetext{
${ }^{38}$ See Flandreau, Flores, Gaillard and Nieto-Para [30].

${ }^{39}$ See id.; see also Flandreau, Gaillard and Packer [31].
} 
[Insert Table 4 and Table 5]

Based on these results, we are left with an initial indication that law firms might have replaced bankers as reputational intermediaries in the post-war period. Flandreau et al. may be right about the enhanced role of rating agencies during the post-war period; but our results suggest the possibility that lawyers may also be part of the story. An aspect of these results that is important is the designated underwriter counsel phenomenon mentioned earlier. This phenomenon shows up in the data on investment bankers and investment banker's counsel, where we see that even though the investment bankers who are lead managers on the deals for a particular sovereign change frequently, the investment banker's lawyers remain the same.

As Figures 5 and 9 illustrate, there is a difference in the strength of the bankerissuer relationship and the banker's lawyer-issuer relationships. At first cut, this looks puzzling. The closeness of the relationships between bankers and issuers and banker's lawyers and issuers should be the same or at least similar. After all, one would presume that the bankers would hire their own lawyers. Yet, what we see, particularly after around 1980, are short duration relationships between sovereign issuers and their bankers, but long duration relationships between those same sovereign issuers and the banker's lawyers. What we are seeing is the manifestation of the practice of utilizing "designated underwriter counsel" - where the issuer chooses an outside law firm and designates them to work on the underwriter's side. The emergence of this phenomenon is important for our purposes. The fact that the investment banker tolerates the issuer choosing the investment banker's law firm might be an indication that a portion of the gatekeeper role has been passed to the lawyers.

\subsubsection{Two Lawyers versus One}

As noted earlier, the sovereign issuances in our database written under New York and English law fall into two types. On the one hand there are those issuances where two sets of outside law firms work on the transaction, in adversarial capacities (one for the issuer and the other for the underwriter). On the other hand there are transactions in which only one set of outside lawyers are involved. If the outside law firms being hired on these deals are operating primarily as reputational intermediaries, then we should see 
differences between the types of issuers using two outside law firms versus one. And we do.

Table 2 reports the statistics on the one versus two lawyer distributions in the period 1946-2012 for 1,063 issuances. The first panel pertains to the full sample. Of the high-rated issuances (investment grade), roughly 30 percent use two outside law firms. The majority of these issuances (over 50 percent) use only one outside law firm. The numbers are reversed if we look at the patterns for non-investment grade issuers. In this subsample, over 75 percent of the issuances use two outside law firms and fewer than 15 percent use only one outside law firm (See Figure 10).

\section{[Insert Figure 10]}

We next break the data down into New York and English law subgroups. In prior work, we found that stronger issuers have tended to use the English market and weaker ones the New York market. ${ }^{40}$ It also could be the case that the difference between the use of one or two law firms is due to the different quality of bonds or the different legal cultures in New York versus London. The second and third panels of Table 2 suggest that this is not the case. In both markets we find that non-investment grade issuers are more likely to use two outside law firms. Investment grade issuers are more likely to use one outside law firm. That said, there are differences in the patterns across the markets - the preference for two-lawyer deals by non-investment grade issuers is stronger in the New York market than in the English market. The reverse applies for the investment grade issuers and their preference for one-lawyer deals (the preference is more distinct in the English market). Figures 11 and 12 illustrate these patterns. Figure 11 reports the number of lawyers working on deals with bonds written under New York law (which is dominated by non-investment grade issuers). The figure shows a larger fraction of twolawyer deals through the period 1980-2012 (prior to 1980, most of the issuances were by investment grade issuers). Figure 12 reports the number of lawyers working on deals involving bonds written under English law, which is dominated by investment grade issuers, and shows the converse - a dominance of one-lawyer deals.

\footnotetext{
${ }^{40}$ See Bradley and Gulati [12].
} 
[Insert Figure 11 and Figure 12]

Table 6 provides a different perspective. It reports on the patterns of lawyer use for the highest volume (by number of deals) issuers. The two halves of the table report the number of sovereigns using two law firms on most of their deals and the number reporting on the sovereigns using one law firm on most of their deals. The patterns are distinct, as the final column, in particular, reveals. The top issuers using two outside law firms are almost all below investment grade. The top issuers using one outside law firm are almost all investment grade.

\section{[Insert Table 6]}

In sum, the behavior of sovereigns in terms of how many outside counsel they hire varies as a function of their reputations as debtors (bond rating). Those with lower ratings typically hire two outside law firms for their deals. Those with higher ratings typically hire one outside law firm. And, as mentioned at the outset, those issuers with the highest reputations (like the United States and Germany) generally utilize no outside law firms on their issuances. Given that the deals do not vary significantly in terms of the technical legal work that needs to be done, something else is likely going on in terms of the hiring of outside counsel. Two possibilities remain. One the one hand, perhaps the weaker issuers perceive a greater need to hire certifiers (two certifiers as opposed to one). On the other hand, it may be that the weaker issuers are more worried about being sued or having assets attached and, therefore, need good lawyers on hand to protect against any legal issues that might arise.

As discussed above, it is possible that two outside law firms on a deal would add more reputational value than only having one firm (the Gilsonian thesis doesn't distinguish between issuer's counsel and underwriter's counsel). When we discussed this premise with practitioners though, some suggested an alternative explanation. The alternate story is that the move to two-lawyer deals in the mid-1990s and thereafter was because weaker issuers, after the crises of the mid-1990s, realized that they could no 
longer afford to have the lawyers for the underwriters set all the terms of the deal; and particularly not the terms governing how the bonds would be restructured if that became necessary. Allowing underwriter's counsel to draft contracts in the absence of a meaningful issuer counsel presence is well and good for strong issuers like Norway and Sweden. Those issuers do not face any meaningful likelihood of default. However, allowing underwriter's counsel to set the contract terms is too costly for sovereigns who perceive a meaningful risk of default and subsequent litigation.

\subsubsection{Reputation of Lawyers and the Reputation of Sovereign Issuers}

In this section we examine the relation between lawyers' reputation and the reputation of issuers. We examine whether the high-reputation lawyers tend to limit their representation to high-reputation issuers, as tends to be the case in the corporate market. ${ }^{41}$ Based on the evidence from the corporate bond market, one might expect that the top reputational intermediaries would be careful to not associate themselves with anything but the top rated issuers. That is the basic idea behind gatekeeping; the weaker and less credible are not allowed to pass through the gates without proper certification. Thus, if the top law firms are playing a reputational intermediary role, we should see them limiting their client lists to the strongest issuers - the ones they have investigated and can certify that the offering is of high quality.

Our proxy for lawyer quality is market share. ${ }^{42}$ We assume that the top law firm acting as issuer counsel and underwriter counsel represent the high-quality law firms. Cleary Gottlieb dominates the market for issuer counsel for bonds written under both New York and English law, with market shares of $26 \%$ and $6 \%$, respectively. Sullivan \& Cromwell dominates the underwriter counsel with an overall market share of $18 \%$ and a market share of $31 \%$ of those bonds written under New York law.

Table 7 reports the relations between the quality of the lawyers based on market share and the quality of the bonds they issue. We divide the sample of bonds into two

\footnotetext{
${ }^{41}$ E.g., Fang [24], Livingston and Miller [49].

${ }^{42}$ Market share is a commonly used measure of reputation, particularly when adequate substitute measures are not available. E.g., Fang [24], Megginson and Weiss [50]. In the sovereign context, we are unaware of any rankings of global law firms in terms of the quality of their sovereign practices. In the context of other research, we have spoken extensively to practitioners and examined the memberships on key international law reform committees for sovereign debt issues. The law firms who have the largest market share are the ones considered by practitioners to have the highest quality members who, in turn, also tend to be on major law reform committees. E.g., Gelpern and Gulati [38], Gulati and Scott [42].
} 
groups: those issues with an S\&P rating of B- or lower (non-investment grade) and those with ratings higher than B- (investment grade).

In Table 7 we report the percentage of issuer counsel and investment bank counsel by jurisdiction and by bond rating. The table shows that the majority of bonds overseen by Cleary Gottlieb, the top issuer counsel, are non-investment grade: $67 \%$ of the total and $64 \%$ and $73 \%$ for New York law and English law bonds, respectively. Similarly, the majority of deals in which the top underwriter counsel, Sullivan \& Cromwell, participated were non-investment grade bonds. Note that this pattern does not hold in the market for English law bonds. However, Sullivan \& Cromwell worked on only 3 deals on bonds written under English law. In sum, the results in Table 7 refute the notion that high-quality lawyers represent high-quality sovereign issues. Apparently, high-rated issuers do not find the need to hire the most prestigious law firms. It is the weaker issuers who manifest this need.

\section{[Insert Table 7]}

The patterns we find for both issuer and underwriter counsel are at odds with the predictions from the reputational intermediary theory because the data reveal a negative relation between the reputation of the issuer law firms and the quality of the issuances that they oversee. High-reputation law firms work with weaker issuers and lowreputation law firms work with stronger issuers. If we assume that the higher-reputation firms are the ones that charge higher rates, this means that the stronger issuers are willing to spend less on legal fees than their weaker counterparts. These results appear stronger still, if one recollects the fact that the strongest issuers (the AAA issuers like the U.S., Denmark, France, etc.) do their sovereign issuances without any lawyers at all. In sum, we find that the strong issuers have no need to rely on outside law firms for their stamp of approval. It is the weak issuers who hire top lawyers. Perhaps this is because they anticipate more trouble in the future than strong issuers. If so, our results are more consistent with the traditional conception of lawyers as people one goes to when one is in trouble, rather than lawyers as reputational intermediaries.

\subsubsection{Cost of Capital}


Our final empirical exercise is an examination of the effects of the choice of underwriters' and issuers' counsel on the cost of capital. Table 8 report the results of OLS regressions in which the dependent variable is the spread between the stated rate and the rate on a U.S. Treasury Bond with the same maturity. ${ }^{43}$ Results are presented for all jurisdictions (Cols. 1-3), New York law (Cols. 4-6) and English law (Cols. 7-9).

The results reported in first column in the each of the samples (Cols.1, 4, and 7) include all independent variables. We divide the bond ratings into six categories (AAA, $\mathrm{AA}, \mathrm{A}, \mathrm{BBB}, \mathrm{BB}, \mathrm{B})$ and combine ratings of pluses and minuses into these respective six categories. Category BBB is our hold out rating. Thus, we expect that all ratings above BBB will have negative coefficients and all below positive ones - and they do. The control variables include the issue's size, maturity and the number of banks in the underwriting syndicate. The regressions include year and currency fixed effects and standard errors that are clustered by country. ${ }^{44}$

The coefficients on the ratings categories are monotonic and all but a few are statistically significant. No other independent variable is statistically significant.

The data reported in columns 2, 5, and 7 exclude the ratings dummies. Aside from a negative relation between Amount and Spread the only other independent variable that is significant is the dummy variable for issuances involving two law firms. Consistent with our previous discussion and empirical evidence, the sign of this coefficient is positive, suggesting that hiring two lawyers yields a higher cost of debt relative to hiring one lawyer, which is the un-coded category. Note that this relation is significant for the U.S. sample, and non-existent in the English sample. Note also that the dummy variables are insignificant when ratings are included in the model. This is not

\footnotetext{
${ }^{43}$ Discussions with practitioners suggest that, because of complications arising from tax treatment, sovereign bonds of the type that we examine (foreign law governed) are almost always issued at par. That said, researchers have found instances where sovereigns have tried to manipulate the coupon rates on the face of their bonds to help satisfy external benchmarks (e.g., imposed by the IMF or the Maastricht Treaty) Dias et al. [23]. These manipulations can occur in a variety of ways, including adjusting the fees paid to financial institutions, using implicit guarantees from third parties, and issuing the bonds at a discount. While our understanding is that the coupon rate manipulation in particular is rare in the context of the foreign law bonds, our analysis is vulnerable to the criticism that we have not fully corrected for them.

${ }^{44}$ Our sample consists of those sovereigns who chose to issue bonds at a particular time. Presumably, there were sovereigns who considered issuing bonds at the same time but decided not to do so. All regressions were re-run with the Inverse Mills ratio, which corrects for this bias. None of our results are affected by the inclusion this variable.
} 
surprising, since according to our earlier findings, there is a negative relation between ratings and the number of lawyers.

Finally, Columns 3, 6 and 9 report regressions in which only two parameters are estimated: a dummy variable equal to 1 if the issue had Issuer Counsel and a dummy variable equal to 1 if the issue involved no lawyers. Under this specification, the estimates of the former imply a higher cost of capital in all three samples - the total, New York law and English law. As detailed above, in the majority of cases, if an issuer hires an outside counsel then that lawyer is most likely to be the underwriter counsel as well. Consequently this variable captures the effect of having 2 lawyers as opposed to 1 . The estimated coefficient is highly significant and material. The t-statistic is greater than 3 and the estimate is greater than 100 basis points in all three samples. Moreover, consistent with the above, the coefficient on the No Lawyer dummy is negative, indicating a significantly lower cost of capital.

\section{[Insert Table 8]}

To summarize, we find consistent evidence that the cost of capital to a sovereign is lower when there are no outside lawyers involved in the transaction compared to issuances involving only one-lawyer. Moreover we find that relative to the cost of capital in one-lawyer transactions, issuances involving two law firms result in a higher cost of capital. The implication of these results is either: (1) lawyers create costs which are reflected in the rate the sovereigns are required to pay; or (2) the presence of lawyers suggests that litigation is a real possibility, especially for risky (non-investment) grade debt. Seeing no direct link between underwriter and lawyer fees and the interest rate that sovereigns face in the market, we suspect the latter. By our interpretation of the evidence, only weaker sovereigns have an incentive to hire outside counsel. Moreover, when the issuer hires not only an underwriter counsel but retains a law firm to protect its interests in negotiating with the underwriter, i.e., an issuer counsel, the cost of capital increases even more. This suggests that investors become skeptical when there are two law firms working on a deal and they respond accordingly by demanding a higher interest rate. However, as we discuss in the conclusion, this is a matter for further research. 


\section{Conclusion}

Research by Marc Flandreau and others indicate that underwriters have ceased to play a gatekeeping role in the sovereign debt markets in the modern era. This raises the question of whether law firms might have stepped in to fill the role previously played by underwriters.

Consistent with the findings of Flandreau et al., we document a sea change in the relationship between sovereign issuers and outside law firms. Prior to WW II, lawyers were nowhere to be found in the sovereign debt market. But after the war, law firms began to get involved in the issuance process. Our initial premise was that lawyers replaced investment banks as the gatekeepers of this market. The evidence suggests that this is not the case. Rather, the results suggest that it is the rating agencies that have stepped in to fill the void left by investment banks,

Our results have implications for the role that lawyers play in this market. We show, in a number of different ways, that the hiring of lawyers correlates with an increase in the cost of capital. Hiring one law firm increases the cost of capital and hiring two law firms increases the cost of capital even more. So, the question is, why would any sovereign issuer hire a law firm? The answer, we suspect, has to do with the types of firms that are hiring outside law firms. The evidence indicates that the weaker the issuer, the greater the need for outside lawyers.

The timing of the shift towards two-lawyer deals reinforces our suspicion. The first instance of a two-lawyer issuance in our data comes as early as 1963 in an issuance by Japan (Milbank Tweed was the first issuer's counsel to show up explicitly on a sovereign bond deal). In 1964, there are three more two-lawyer issuances, by Austria, Japan and Norway. However, employing two law firms does not become prevalent until the mid-1990s (roughly 1996-98); and when it does, the impetus comes from the big Latin American issuers such as Mexico and Brazil. The 1995-98 period is significant in sovereign debt history because it is the period that covers both the Tequila crisis in Mexico (1995) and the Asian Financial Crisis (1997-98). In addition to the crises though, this period also witnessed a significant expansion in both the number of deals being done and the types of issuers doing them. Crucially, many more low-rated sovereign issuers entered the markets. Perhaps the combination of multiple financial crises in the mid- 
1990s and the expansion in the types of issuers increased the need for mechanisms that provided enhanced credibility. The data in Figures 11 and 12 show that in the 1950s and 1960s, the fraction of deals using two law firms was 0 , and while the number increases in the 1970s and 1980s, the number of deals involving two sets of law firms was only in the 10-20 percent range. The big change in terms of these types of deals constituting the majority of all deals being done begins around the mid to late 1990s. By 2011, the fraction of deals using two outside law firms was over 75 percent of all the sovereign issuances written under New York and English law.

The question then becomes what happened as a result of the crisis period of the mid-1990s that caused this apparent enhanced need for lawyers. The historical record suggests two related changes that occurred that may have impacted the need for lawyers, and in particular the need for lawyers on the issuer side for the weakest sovereign issuers. First, the mid-1990s is when we observe the emergence of the modern vulture creditor. That is, a creditor who holds out and refuses a sovereign's restructuring offer and then sues in court for the full amount. In earlier eras, holding out would have been a largely pointless exercise, since the sovereign, with its lawyers and large resource base, could simply outlast the creditors. In the mid-1990s a new type of creditor emerged - one with the resources and litigation skills to be able to take on a sovereign debtor in court and, on occasion, even win. It is in 1995-96 that the first major vulture victory occurred with the litigation by the Styrofoam magnate Kenneth Dart against Brazil (Dart is rumored to have made upwards of $\$ 1$ billion from the eventual settlement). ${ }^{45}$ Following on the heels of that decision was a series of litigations led by the billionaire Paul Singer's hedge fund, Elliott Associates, against countries like Panama, Peru, Congo and Argentina. ${ }^{46}$ Today, there are numerous such hedge funds in existence - each with sophisticated sovereign litigators on hand. The historical evidence suggests, therefore, that it might be the enhanced need for sovereigns to have protection against litigation by vulture creditors

\footnotetext{
${ }^{45}$ The litigation was in 1995. CIBC Bank and Trust Co. (Cayman), Ltd. v. Banco Central do Brasil, 886 F. Supp. 1105 (S.D.N.Y. 1995). See also Schumacher, Trebesch and Enderlein [57].

46 These cases are described in Blackmun and Mukhi [10].
} 
that produced the need for issuer's counsel; a need that emerges full blown only in the mid-1990s. $^{47}$

The second and related change that also, arguably, helped enhance the need for lawyers was the increased reluctance by official sector institutions (e.g., the IMF) to provide bailouts for sovereigns in trouble. This, in turn, meant that sovereign debtors who were in trouble had to come up with creative ways to engineer restructurings within the context of the debt contracts that they had agreed to. Put simply, the terms of the contracts the sovereigns had signed started becoming increasingly important. Starting in the late 1990s, a number of weaker sovereign issuers began having to do restructurings, with little or no official sector assistance (other than a "do it yourself" exhortation from institutions like the IMF). Pakistan, Ukraine, and Ecuador were among the early movers, whose experiences taught the rest of the market that having lawyers who knew how to work with contract terms was important; at least for the weaker issuers. ${ }^{48}$

To summarize, our results indicate that sovereigns increasingly turned to law firms in the post-World War II period, and especially so in the mid-1990s. Part of this trend is due to the increased perceptions of risk after crises such as the Latin American crisis of the 1980s. But the most significant part of the story, we conjecture, relates to the enhanced litigation risk that sovereign issuers began to face starting in the mid-1990s. ${ }^{49}$

Before concluding, we note a couple of caveats.

First, our analysis has focused on the demand side of this market. However, supply side effects might be at play as well. The structure of the modern law firm has evolved significantly over the 200 year period that we examine, going from associations with no more than a few lawyers in the $19^{\text {th }}$ century, to relatively small firms in the early $20^{\text {th }}$ century, to the mega firms of the 1990s and thereafter (Galanter and Palay [35], Wilkins [63]). And while many of those developments were likely client-demand driven, it is hard to fully separate those from the effects of things like the major changes in communication, transportation, and regulatory philosophies that took place over that

\footnotetext{
${ }^{47}$ For more on vulture litigation against sovereigns, see Allegaert [2], Fisch and Gentile [27], Alfaro, Ahmed and Maurer [1]. Thompson and Runciman [61], Gulati and Scott [42].

${ }^{48}$ For details, see Sturzeneger and Zettelmeyer [60], Das, Papaioannou, and Trebesch [20].

${ }^{49}$ Meaningful litigation against sovereigns became possible in the U.S. and U.K., in theory, in the late 1970s, after the passage of the Foreign Sovereign Immunities Act in the U.S. in 1976 and the State Immunities Act in the U.K. in 1976. However, it took a decade and a half for specialist firms to emerge that had the financial resources and litigation skills to conduct effective litigations against sovereigns.
} 
period. A fuller study could incorporate the impact of supply side developments into the sovereign debt market. For our purposes though, the most relevant portion of our analysis is our empirical inquiry over the period 1990-2011, in which we examine the differences between sovereigns hiring either zero, one or two large elite law firms. In this context, because we are essentially looking at choices made by different sovereign issuers contemporaneously, the supply side is not particularly relevant (it affects both sides of the analysis in the same way).

Second, our interpretation of the evidence may be changing even as we write this in August 2013. At this time, the sovereign debt markets are in turmoil. The past couple of years have not only witnessed a major crisis in the sovereign debt markets (the Euro area crisis), but have also seen the biggest sovereign debt restructuring in history (Greece, in March $2012^{50}$ ) and one of the most effective litigations against a sovereign (NML v. Argentina, in October $2012^{51}$ ). Based on the findings in this paper, we may be on the cusp of seeing another significant change in the roles played by lawyers in sovereign debt transactions.

\section{Acknowledgements}

Thanks to participants at conferences at George Mason University Law School and the Graduate Institute in Geneva for helpful comments. Thanks also to the anonymous referees for their suggestions. Finally, a special thanks to Bruce Kobayashi and Henry Butler for including us in their conference in memory of Larry Ribstein and his pioneering work on lawyers and law firms.

\section{References}

[1] L. Alfaro, F. Ahmed, N. Maurer, Lawsuits and Empire: On the Enforcement of Sovereign Debt in Latin America, L \& Contemp. Prob. 73 (2010) 39-47.

[2] T. Allegaert, Recalcitrant Creditors Against Debtor Nations or How to Play Darts, Minn. J. Global Trade 6 (1997) 429-471

[3] S. M. Bainbridge, Corporate Lawyers as Gatekeepers, S. Bainbridge, Corporate Governance after the Financial Crisis, Oxford University Press, (2012).

[4] J. Barnett, Certification Drag: The Opinion Puzzle and Other Transactional Curiosities, J. Corp. L. 33, 1 (2008) 95-146.

${ }^{50}$ Zettelmeyer, Trebesch and Gulati [64].

${ }^{51}$ See NML Capital Ltd. V. Republic of Argentina, 699 F.3d 246 (2d Cir. 2012). 
[5] J. Barnett, Intermediaries Revisited: Is Efficient Certification Consistent with Profit Maximization? J. Corp. L. 37,3 (2012) 475-522.

[6] R. R. Barondes, C. Nyce, G. Sanger, Underwriters' Counsel as Gatekeeper or Turnstile: An Empirical Analysis of Law Firm Prestige and Performance in IPOs, Cap. Mkts. L. J. 2, 2 (2007) 164 -190.

[7] F. J. Batlan, The Imperial SEC: Foreign Policy and the Internationalization of the Securities Markets 19341990, U.S. Securities and Exchange Commission Historical Society (2008).

[8] R. P. Beatty, I. Welch, Issuer Expenses and Legal Liability in Initial Public Offerings, J.L. \& Econ. 39, 2 (1996) 545-602.

[9] J. D. Bennett, The London Confederates: The Officials, Clergy, Businessmen, and Journalists Who Backed the American South During the Civil War, McFarland Press (2008).

[10] J. I. Blackmun, R. Mukhi, The Evolution of Modern Sovereign Debt Litigation: Vultures, Alter Egos and Other Legal Fauna, L \& Contemp. Prob. 73 (2010) 47-61.

[11] M. Bradley, J. D. Cox, M. Gulati, The Market Reaction to Legal Shocks and Their Antidotes: Lessons from the Sovereign Debt Market, J. Legal Stud. 39, 1 (2010) 289-324.

[12] M. Bradley, M. Gulati, Collective Action Clauses for the Eurozone: An Empirical Analysis, Rev. Fin. Stud (forthcoming, 2013).

[13] L. C. Buchheit, The Sovereign Client, J. Int'l Affairs 48, 2 (1995) 531-532.

[14] L.C. Buchheit and M. Gulati, The Gathering Storm: Contingent Liabilities in a Sovereign Debt Restructuring (2013), available at http://papers.ssrn.com/sol3/papers.cfm?abstract_id=2292669

[15] M. Buti, J. N. Martins, and A. Turrini, From Deficits to Debt and Back: Political Incentives under Numerical Fiscal Rules, CESifo Econ. Stud. 53 (2007) 115-152.

[16] W. J. Carney, G. W. Dent Jr., R. J. Gilson, Keynote Discussion: Just What Exactly Does a Transactional Lawyer Do?, Tenn. J. Bus. L. 12 (2011) 175-186.

[17] R. Carter, F. Dark, A. Singh, Underwriter Reputation, Initial Returns, and the Long-Run Performance of IPO Stocks, J. Fin. 53, 1 (1998) 285-311.

[18] T. Chemmanur, P. Fulghieri, Investment Bank Reputation, Information Production, and Financial Intermediation, J. Fin. 49, 1 (1994) 57-79.

[19] W. R. Cline, International Debt Reexamined, Institute for International Economics Press (1995).

[20] U. Das, M. Papaioannou, C. Trebesch, Sovereign Debt Restructurings 1950-2010: Literature Survey, Data and Stylized Facts, IMF Working Paper 12/203 (2012)

[21] G. W. Dent Jr., Business Lawyers as Enterprise Architects, Bus. Law. 64, 2 (2009) 279-327.

[22] D. Diamond, Reputation Acquisition in Debt Markets, J. Pol. Econ. 94, 4 (1989) 828-862.

[23] D. A. Dias, C. J. Richmond, M. L.J. Wright, The Stock of External Sovereign Debt: Can We Take the Data at 'Face Value'? (2011), NBER Working Paper 17551.

[24] L. Fang, Investment Bank Reputation and the Price and Quality of Underwriting Services, J. Fin. 60, 6 (2005) 2729-2761.

[25] N. Ferguson, The House of Rothschilds, Volume 1: Money’s Prophets 1798-1848, Penguin Books (1999).

[26] N. Ferguson, The House of Rothschilds Volume 2: The World's Banker 1849-1999, Penguin Books (2000).

[27] J. E. Fisch, C. M. Gentile, Vultures or Vanguards?The Role of Litigation in Sovereign Debt Restructuring, Emory L. J. 53, 3 (2004) 1043-1113.

[28] M. Flandreau, J. Flores, Bonds and Brands: Intermediaries and Reputation in Sovereign Debt Markets 18201830, J. Econ. Hist. 69, 3 (2009) 646-684.

[29] M. Flandreau, J. H. Flores, Bondsellers versus Bondholders: Investment Banks and Conditionality Lending in the London Market for Foreign Government Debt 1815-1913, Eur. Rev. Econ. Hist. 16, 4 (2012) 356-383.

[30] M. Flandreau, J. H. Flores, N. Gaillard, S. Nieto-Parra, The End of Gatekeeping: Underwriters and the Quality of Sovereign Bond Markets 1815-2007, NBER Working Paper 15128 (2009).

[31] M. Flandreau, N. Gaillard, F. Packer, To Err is Human: US Rating Agencies and the Interwar Foreign Government Debt Crisis, Eur. J. Econ. Hist. 15, 3 (2011) 495-538.

[32] M. Flandreau, N. Gaillard, U. Panizza, Conflicts of Interest, Reputation, and the Interwar Debt Crisis, Banksters or Bad Luck? HEID Working Paper 2 (2010)

[33] J. H. Flores, Competition in the Underwriting Markets of Sovereign Debt: The Barings Crisis Revisited, L. \& Contemporary Problems 73, 4 (2010) 129-150.

[34] S. Foote, The Civil War: A Narrative, Random House (1958).

[35] M. Galanter and T. Palay, Tournament of Lawyers, University of Chicago Press (1991). 
[36] P. J. Gardner, A Role for the Business Attorney in the Twenty-First Century: Adding Value to the Client's Enterprise in the Knowledge Economy, Marq. Intell. Prop. L. Rev. 7, 1 (2003) 17-39.

[37] S. Gatti, S. Kleimeier, W. L. Megginson, A. Steffanoni, Arranger Certification in Project Finance (2008). Available at SSRN: http://ssrn.com/abstract $=968289$

[38] A. Gelpern, G. M. Gulati, The Wonder-Clause, J. Comp. Econ. 47, 2 (2013) 367-385.

[39] J. F. Gentry, A Confederate Success in Europe: The Erlanger Loan, J. Southern Hist. 36, 2 (1970) 157-188.

[40] R. J. Gilson, Value Creation by Business Lawyers: Legal Skills and Asset Pricing, Yale L. J. 94, 2 (1984) 239-313.

[41] R. J. Gilson, R. H. Mnookin, Foreword: Business Lawyers and Value Creation for Clients, Or. L. Rev. 74 (1995) 1-14.

[42] G. M. Gulati, R. Scott, The 31/2 Minute Transaction: Boilerplate and the Limits of Contract Design, University of Chicago Press (2012).

[43] T. C. Irwin, Accounting Devices and Fiscal Illusions (2012), IMF Staff Papers.

[44] C. James, Relationship-Specific Assets and the Pricing of Underwriter Services, J. FIN. 47, 5 (1992) 18651885.

[45] G. Z. Jin, A. Kato, J. List, That's News to Me! Information Revelation in Professional Certification Markets, Econ. Inquiry 48, 1 (2010) 104-122.

[46] S. H. Kim, Lawyer Exceptionalism in the Gatekeeping Wars, SMU L. Rev. 63, 1 (2010) 73-135.

[47] D. B. Klein, Reputation: Studies in the Voluntary Elicitation of Good Conduct, University of Michigan Press (1997).

[48] J. Lipshaw, The Mythology of Value Creation: Lawyers, Neckties and Balinese Cock Fighting, The Conglomerate, Oct. 23, 2008, available at http://www.theconglomerate.org/2008/10/the-mythology-o.html.

[49] M. Livingston, R. Miller, Investment Bank Reputation and the Underwriting of Nonconvertible Debt, Fin. Mgt. 29, 2 (2000) 21-34.

[50] W. L. Megginson, K. A. Weiss, Venture Capitalist Financing in Initial Public Offerings, J. Fin. 46 (1994) 879-903.

[51] P. Milgrom, J. Roberts, Predation, Reputation, and Entry Deterrence, J. Econ. Theory 27, 2 (1982) 280-312.

[52] K. S. Okamoto, Reputation and the Value of Lawyers, Or. L. Rev. 74, 1 (1995) 15-55.

[53] S. Y. Rauterkus, K. Song, Auditor's Reputation, Equity Offerings, and Firm Size: The Case of Arthur Andersen, San Diego Meetings (2004).

[54] L. E. Ribstein, Ethical Rules, Agency Costs and Law Firm Structure, Va. L. Rev. 84, 8 (1998) 1707-1759.

[55] L. E. Ribstein, The Death of Big Law, Wisc. L. Rev. 2010, 3 (2010) 749-813

[56] J. G. Riley, Silver Signals: Twenty-Five Years of Screening and Signaling, J. Econ Lit. 39, 2 (2001) 432-478.

[57] J. Schumacher, C. Trebesch, H. Enderlein, Sovereign Defaults in Court-The Rise of Creditor Litigation 1976 -2010 (2013 draft), available at http://papers.ssrn.com/sol3/papers.cfm?abstract_id=2189997.

[58] S. L. Schwarcz, Explaining the Value of Transactional Lawyering, Stan. J. L. Bus. \& Fin. 12, 2 (2007) 486507.

[59] C. Shapiro, Premiums for High Quality Products as Returns to Reputations, Q. J. Econ. 98, 4 (1983) 659-680.

[60] F. Sturzenegger, J. Zettelmeyer, Debt Defaults And Lessons From A Decade Of Crises, MIT Press (2006).

[61] H. Thompson, D. Runciman, Sovereign Debt and Private Creditors: New Legal Sanction or the Enduring Power of States? New Pol. Econ. 11, 4 (2006) 541-555

[62] M. D. Weidenmier, The Market for Confederate Bonds, Explorations Econ 37,1 (2000) 76-97.

[63] D. B. Wilkins, Team of Rivals? Toward a New Model of the Corporate Attorney-Client Relationship, Fordham L. Rev., 78, 5 (2010) 2067-2135.

[64] J. Zettelmeyer, C. Trebesch, M. Gulati, The Greek Debt Exchange: An Autopsy, Economic Policy 28, 75 (2013), 513-563. 
Table 1: Top 50 Issuers

\begin{tabular}{|c|c|c|c|c|}
\hline Countries & $1800-1944$ & $1945-2012$ & 1980 - 2012 & Total \\
\hline Argentina & 59 & 52 & 52 & 1111 \\
\hline Australia & 28 & 37 & 15 & 65 \\
\hline Austria & 6 & 30 & 25 & 36 \\
\hline Belgium & 9 & 61 & 58 & 70 \\
\hline Brazil & 23 & 48 & 40 & 71 \\
\hline Canada & 21 & 9 & 3 & 30 \\
\hline Chile & 21 & 11 & 10 & 32 \\
\hline China & 38 & 14 & 14 & 52 \\
\hline Colombia & 9 & 32 & 25 & 41 \\
\hline Costa Rica & 6 & 9 & 9 & 15 \\
\hline Croatia & 0 & 18 & 18 & 18 \\
\hline Cyprus & 2 & 12 & 12 & 14 \\
\hline Czech & 6 & 10 & 10 & 16 \\
\hline Denmark & 3 & 36 & 25 & 39 \\
\hline El Salvador & 1 & 14 & 11 & 15 \\
\hline Finland & 4 & 65 & 60 & 69 \\
\hline France & 16 & 2 & 0 & 18 \\
\hline Germany & 27 & 8 & 2 & 35 \\
\hline Greece & 8 & 48 & 48 & 56 \\
\hline Hungary & 4 & 13 & 13 & 17 \\
\hline Iceland & 3 & 30 & 30 & 33 \\
\hline Indonesia & 0 & 11 & 10 & 11 \\
\hline Ireland & 4 & 28 & 24 & 32 \\
\hline Italy & 6 & 50 & 45 & 56 \\
\hline Jamaica & 4 & 21 & 19 & 25 \\
\hline Japan & 22 & 33 & 16 & 55 \\
\hline Korea & 0 & 11 & 11 & 11 \\
\hline Lebanon & 0 & 21 & 21 & 21 \\
\hline Lithuania & 0 & 20 & 20 & 20 \\
\hline Malaysia & 0 & 19 & 15 & 19 \\
\hline Mexico & 9 & 67 & 55 & 76 \\
\hline New Zealand & 12 & 23 & 17 & 35 \\
\hline Norway & 10 & 39 & 12 & 49 \\
\hline Panama & 4 & 22 & 20 & 26 \\
\hline Peru & 5 & 9 & 9 & 14 \\
\hline Philippines & 0 & 46 & 42 & 46 \\
\hline Poland & 6 & 28 & 28 & 34 \\
\hline Portugal & 2 & 48 & 45 & 50 \\
\hline Romania & 6 & 6 & 6 & 12 \\
\hline Russia & 17 & 17 & 17 & 34 \\
\hline South Africa & 13 & 32 & 19 & 45 \\
\hline Spain & 2 & 14 & 14 & 16 \\
\hline Sweden & 11 & 54 & 49 & 65 \\
\hline Tunisie & 0 & 10 & 10 & 10 \\
\hline Turkey & 3 & 50 & 50 & 53 \\
\hline United Kingdom & 71 & 7 & 7 & 78 \\
\hline Uruguay & 6 & 26 & 26 & 32 \\
\hline Venezuela & 0 & 35 & 30 & 35 \\
\hline Other countries & 105 & 173 & 169 & 278 \\
\hline Total & 612 & 1479 & 1286 & 2091 \\
\hline
\end{tabular}


Table 2: Number of lawyers by law and sovereign bond rating, 1946 - 2012

\begin{tabular}{|c|c|c|c|c|c|c|}
\hline & \multirow{2}{*}{$\begin{array}{c}\text { \# of } \\
\text { lawyers }\end{array}$} & \multicolumn{2}{|c|}{ Non inves tment grade } & \multicolumn{2}{|c|}{ Inves tment grade } & \multirow[t]{2}{*}{ Total } \\
\hline & & Number & $\%$ & Number & $\%$ & \\
\hline \multirow{4}{*}{ All Sample } & 0 & 41 & $8.74 \%$ & 110 & $14.65 \%$ & 151 \\
\hline & 1 & 63 & $13.43 \%$ & 425 & $56.59 \%$ & 488 \\
\hline & 2 & 365 & $77.83 \%$ & 216 & $28.76 \%$ & 581 \\
\hline & Total & 469 & $100.00 \%$ & 751 & $100.00 \%$ & 1220 \\
\hline \multirow{4}{*}{$\begin{array}{c}\text { New York } \\
\text { Law }\end{array}$} & 0 & 2 & $0.67 \%$ & 1 & $0.51 \%$ & 3 \\
\hline & 1 & 17 & $5.70 \%$ & 83 & $42.13 \%$ & 100 \\
\hline & 2 & 279 & $93.62 \%$ & 113 & $57.36 \%$ & 392 \\
\hline & Total & 298 & $100.00 \%$ & 197 & $100.00 \%$ & 495 \\
\hline \multirow{4}{*}{$\begin{array}{c}\text { English } \\
\text { Law }\end{array}$} & 0 & 1 & $0.90 \%$ & 9 & $2.37 \%$ & 10 \\
\hline & 1 & 37 & $33.33 \%$ & 284 & $74.93 \%$ & 321 \\
\hline & 2 & 73 & $65.77 \%$ & 86 & $22.69 \%$ & 159 \\
\hline & Total & 111 & $100.00 \%$ & 379 & $100.00 \%$ & 490 \\
\hline \multirow{4}{*}{$\begin{array}{c}\text { German } \\
\text { Law }\end{array}$} & 0 & 30 & $81.08 \%$ & 56 & $90.32 \%$ & 86 \\
\hline & 1 & 4 & $10.81 \%$ & 6 & $9.68 \%$ & 10 \\
\hline & 2 & 3 & $8.11 \%$ & 0 & $0.00 \%$ & 3 \\
\hline & Total & 37 & $100.00 \%$ & 62 & $100.00 \%$ & 99 \\
\hline
\end{tabular}


Table 3: Two-sample Wilcoxon rank-sum (Mann-Whitney) test for Investment Banks

\begin{tabular}{|c|c|c|c|c|c|c|c|}
\hline \multicolumn{8}{|c|}{ Long Term Relations for the Two Samples Pre and Post WWII } \\
\hline \multicolumn{4}{|c|}{ Specification 1} & \multicolumn{4}{|c|}{$\begin{array}{r}\text { Specification } 2 \\
\end{array}$} \\
\hline $\begin{array}{l}\text { Pre-WWII } \\
\text { dummy }\end{array}$ & obs & rank sum & expected & $\begin{array}{l}\text { Pre-WWII } \\
\text { dummy }\end{array}$ & obs & rank sum & expected \\
\hline 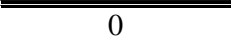 & $1,254.0$ & $1,1,054,317.0$ & $1,032,042.0$ & 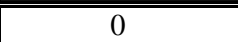 & $1,254.0$ & $1 \overline{1,038,609.0}$ & $1,006,335.0$ \\
\hline 1 & 391.0 & $299,518.0$ & $321,793.0$ & 1 & 350.0 & $248,601.0$ & $280,875.0$ \\
\hline combined & $1,645.0$ & $1,353,835.0$ & $1,353,835.0$ & combined & $1,604.0$ & $1,287,210.0$ & $1,287,210.0$ \\
\hline \multicolumn{4}{|c|}{$\begin{array}{l}\text { Ho: Investment Bank long term relations is the same pre } \\
\text { WWII and post WWII? }\end{array}$} & \multicolumn{4}{|c|}{$\begin{array}{l}\text { Ho: Investment Bank long term relations is the same pre } \\
\text { WWII and post WWII? }\end{array}$} \\
\hline $\begin{array}{c}\mathrm{z}=3.317 \\
\text { Prob }>\mathrm{z}=0.0009\end{array}$ & \multicolumn{3}{|c|}{ Reject the null with $99 \%$} & $\begin{aligned} z & =5.106 \\
\text { Prob }>z & =0.0000\end{aligned}$ & \multicolumn{3}{|c|}{ Reject the null with $99 \%$} \\
\hline \multicolumn{8}{|c|}{ Long Term Relations for the Two Samples Pre and Post 1982} \\
\hline \multicolumn{4}{|c|}{ Specification 1} & \multicolumn{4}{|c|}{$\begin{array}{r}\text { Specification } 2 \\
\end{array}$} \\
\hline Pre-1982 dummy & obs & rank sum & expected & Pre-1982 dummy & obs & rank sum & expected \\
\hline 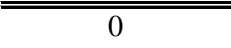 & 141.0 & $1118,941.0$ & $88,477.5$ & 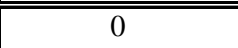 & 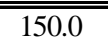 & $120,487.5$ & $93,450.0$ \\
\hline 1 & $1,113.0$ & $667,944.0$ & $698,407.5$ & 1 & $1,095.0$ & $655,147.5$ & $682,185.0$ \\
\hline combined & $1,254.0$ & $786,885.0$ & $786,885.0$ & combined & $1,245.0$ & $775,635.0$ & $775,635.0$ \\
\hline \multicolumn{4}{|c|}{$\begin{array}{l}\text { Ho: Investment Bank long term relations is the same pre } \\
\qquad 1982 \text { and post } 1982 ?\end{array}$} & \multicolumn{4}{|c|}{$\begin{array}{l}\text { Ho: Investment Bank long term relations is the same pre- } \\
\qquad 1982 \text { and post } 1982 \text { ? }\end{array}$} \\
\hline $\begin{aligned} z & =9.346 \\
\text { Prob }>z & =0.0009\end{aligned}$ & \multicolumn{3}{|c|}{ Reject the null with $99 \%$} & $\begin{aligned} z & =7.958 \\
\text { Prob }>z & =0.0000\end{aligned}$ & \multicolumn{3}{|c|}{ Reject the null with $99 \%$} \\
\hline
\end{tabular}


Table 4: Underwriters and Lawyers Long Term Relations Composition by Ratings, 1946 -2012

\begin{tabular}{|c|c|c|c|c|c|c|}
\hline \multicolumn{7}{|c|}{ All sample } \\
\hline & & \multicolumn{2}{|c|}{ Non-investment grade } & \multicolumn{2}{|c|}{ Investment grade } & \multirow[b]{2}{*}{ Total } \\
\hline & & Number & $\%$ of total & Number & $\%$ of total & \\
\hline \multirow{3}{*}{$\begin{array}{l}\text { Issuer } \\
\text { Counsel }\end{array}$} & Change & 54 & $15.21 \%$ & 64 & $11.99 \%$ & 118 \\
\hline & No change & 301 & $84.79 \%$ & 470 & $88.01 \%$ & 771 \\
\hline & Total & 355 & $100.00 \%$ & 534 & $100.00 \%$ & 889 \\
\hline \multirow{3}{*}{$\begin{array}{l}\text { Investment } \\
\text { Bank Counsel }\end{array}$} & Change & 70 & $20.83 \%$ & 134 & $25.87 \%$ & 204 \\
\hline & No change & 266 & $79.17 \%$ & 384 & $74.13 \%$ & 650 \\
\hline & Total & 336 & $100.00 \%$ & 518 & $100.00 \%$ & 854 \\
\hline \multirow{3}{*}{$\begin{array}{l}\text { Investment } \\
\text { Bank }\end{array}$} & Change & 265 & $66.75 \%$ & 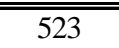 & $76.69 \%$ & 788 \\
\hline & No change & 132 & $33.25 \%$ & 159 & $23.31 \%$ & 291 \\
\hline & Total & 397 & $100.00 \%$ & 682 & $100.00 \%$ & 1,079 \\
\hline \multicolumn{7}{|c|}{ New York Law } \\
\hline & & \multirow{2}{*}{\multicolumn{2}{|c|}{$\begin{array}{l}\text { Non-investment grade } \\
\text { Number } \% \text { of total }\end{array}$}} & \multicolumn{2}{|c|}{ Investment grade } & \\
\hline & & & & Number & $\%$ of total & Total \\
\hline \multirow{3}{*}{$\begin{array}{l}\text { Issuer } \\
\text { Counsel }\end{array}$} & Change & 34 & $12.98 \%$ & 19 & $11.24 \%$ & 53 \\
\hline & No change & 228 & $87.02 \%$ & 150 & $88.76 \%$ & 378 \\
\hline & Total & 262 & $100.00 \%$ & 169 & $100.00 \%$ & 431 \\
\hline \multirow{3}{*}{$\begin{array}{l}\text { Investment } \\
\text { Bank Counsel }\end{array}$} & Change & 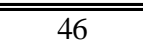 & $=18.40 \%$ & $\overline{50}$ & $30.30 \%$ & 96 \\
\hline & No change & 204 & $81.60 \%$ & 115 & $69.70 \%$ & 319 \\
\hline & Total & 250 & $100.00 \%$ & 165 & $100.00 \%$ & 415 \\
\hline \multirow{3}{*}{$\begin{array}{l}\text { Investment } \\
\text { Bank }\end{array}$} & Change & 177 & $666.79 \%$ & 125 & $=70.22 \%$ & 302 \\
\hline & No change & 88 & $33.21 \%$ & 53 & $29.78 \%$ & 141 \\
\hline & Total & 265 & $100.00 \%$ & 178 & $100.00 \%$ & 443 \\
\hline \multicolumn{7}{|c|}{ English Law } \\
\hline & & \multirow{2}{*}{\multicolumn{2}{|c|}{$\begin{array}{l}\text { Non-investment grade } \\
\text { Number } \% \text { of total }\end{array}$}} & \multicolumn{2}{|c|}{ Investment grade } & \\
\hline & & & & Number & $\%$ of total & Total \\
\hline \multirow{3}{*}{$\begin{array}{l}\text { Issuer } \\
\text { Counsel }\end{array}$} & Change & 18 & $23.38 \%$ & 38 & $12.50 \%$ & 56 \\
\hline & No change & 59 & $76.62 \%$ & 266 & $87.50 \%$ & 325 \\
\hline & Total & 77 & $100.00 \%$ & 304 & $100.00 \%$ & 381 \\
\hline \multirow{3}{*}{$\begin{array}{l}\text { Investment } \\
\text { Bank Couns el }\end{array}$} & Change & 18 & $25.00 \%$ & 257 & $19.19 \%$ & 75 \\
\hline & No change & 54 & $75.00 \%$ & 240 & $80.81 \%$ & 294 \\
\hline & Total & 72 & $100.00 \%$ & 297 & $100.00 \%$ & 369 \\
\hline \multirow{3}{*}{$\begin{array}{l}\text { Investment } \\
\text { Bank }\end{array}$} & Change & 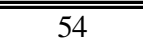 & $666.67 \%$ & 275 & $79.02 \%$ & 329 \\
\hline & No change & 27 & $33.33 \%$ & 73 & $20.98 \%$ & 100 \\
\hline & Total & 81 & $100.00 \%$ & 348 & $100.00 \%$ & 429 \\
\hline
\end{tabular}


Table 5: Two-sample Wilcoxon rank-sum (Mann-Whitney) test for Investment Bank Long Term Relations for Two Samples, post-WWII

\begin{tabular}{|c|c|c|c|c|c|c|c|c|c|c|c|}
\hline \multicolumn{4}{|c|}{ Issuers counsel and Underwriters counsel } & \multicolumn{4}{|c|}{ Issuers counsel and Investment Bank } & \multicolumn{4}{|c|}{ Underwriters counsel and Inves tment Bank } \\
\hline & obs & rank sum & expected & & obs & rank sum & expected & & obs & rank sum & expected \\
\hline 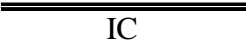 & 979.0 & $929,029.0$ & & $\overline{\mathrm{IC}}$ & $1,254.0$ & $1,073,074.0$ & $1,432,6$ & IB & $1,254.0$ & $1,125,701.5$ & $1,400,718.0$ \\
\hline IBC & 030.0 & $1,090,016.0$ & 1,035 & IB & $1,030.0$ & $1,536,396.0$ & $1,176,7$ & IBC & 979.0 & $1,368,559.5$ & $1,093,543.0$ \\
\hline combined & $2,009.0$ & $2,019,045.0$ & $2,019,045.0$ & combined & $2,284.0$ & $2,609,470.0$ & $2,609,470.0$ & combined & $2,233.0$ & $2,494,261.0$ & $2,494,261.0$ \\
\hline \multicolumn{4}{|c|}{$\begin{array}{l}\text { Ho: Iss uers counsel and Underwriters counsel change is } \\
\text { the same? }\end{array}$} & \multicolumn{4}{|c|}{$\begin{array}{l}\text { Ho: Issuers counsel and Investment Bank change is the } \\
\text { same? }\end{array}$} & \multicolumn{4}{|c|}{$\begin{array}{l}\text { Ho: Underwriters counsel and Investment Bank change } \\
\text { is the same? }\end{array}$} \\
\hline $\begin{aligned} z & =-6.328 \\
\text { Prob }>z & =0.0000\end{aligned}$ & \multicolumn{3}{|c|}{ Reject the null with $99 \%$} & $\begin{array}{c}z=-26.713 \\
\text { Prob }>z=0.0000\end{array}$ & \multicolumn{3}{|c|}{ Reject the null with $99 \%$} & $\begin{array}{c}z=-21.011 \\
\text { Prob }>z=0.0000\end{array}$ & \multicolumn{3}{|c|}{ Reject the null with $99 \%$} \\
\hline
\end{tabular}


Table 6: Top countries with one and two lawyers, all laws, 1946 - 2012

\begin{tabular}{|c|c|c|c|c|c|c|c|c|c|}
\hline \multirow[t]{2}{*}{ Country } & \multicolumn{2}{|c|}{ No lawyer } & \multicolumn{2}{|c|}{ One lawyer } & \multicolumn{2}{|c|}{ Two lawyers } & \multirow[t]{2}{*}{ Total } & \multirow[t]{2}{*}{ Spread } & \multirow{2}{*}{$\begin{array}{c}\text { Investment } \\
\text { grade }\end{array}$} \\
\hline & Number & $\%$ of total & Number & $\%$ of total & Number & $\%$ of total & & & \\
\hline & \multicolumn{9}{|c|}{ Top countries with two lawyers } \\
\hline Poland & 1 & $3.57 \%$ & 0 & $0.00 \%$ & 27 & $96.43 \%$ & 28 & 1.221 & $96.15 \%$ \\
\hline Uruguay & 1 & $3.85 \%$ & 0 & $0.00 \%$ & 25 & $96.15 \%$ & 26 & 2.302 & $38.46 \%$ \\
\hline Lebanon & 0 & $0.00 \%$ & 2 & $9.52 \%$ & 19 & $90.48 \%$ & 21 & 3.198 & $5.26 \%$ \\
\hline Brazil & 4 & $8.33 \%$ & 3 & $6.25 \%$ & 41 & $85.42 \%$ & 48 & 3.428 & $27.08 \%$ \\
\hline Colombia & 3 & $9.38 \%$ & 5 & $15.63 \%$ & 24 & $75.00 \%$ & 32 & 3.770 & $44.44 \%$ \\
\hline Venezuela & 5 & $14.29 \%$ & 4 & $11.43 \%$ & 26 & $74.29 \%$ & 35 & 3.620 & $0.00 \%$ \\
\hline Philippines & 3 & $6.52 \%$ & 10 & $21.74 \%$ & 33 & $71.74 \%$ & 46 & 3.188 & $0.00 \%$ \\
\hline Argentina & 16 & $30.77 \%$ & 2 & $3.85 \%$ & 34 & $65.38 \%$ & 52 & 3.868 & $0.00 \%$ \\
\hline Mexico & 5 & $7.46 \%$ & 23 & $34.33 \%$ & 39 & $58.21 \%$ & 67 & 2.503 & $30.00 \%$ \\
\hline \multirow[t]{2}{*}{ Turkey } & 10 & $20.00 \%$ & 16 & $32.00 \%$ & 24 & $48.00 \%$ & 50 & 5.107 & $12.00 \%$ \\
\hline & \multicolumn{9}{|c|}{ Top countries with one lawyer } \\
\hline Italy & 2 & $4.00 \%$ & 48 & $96.00 \%$ & 0 & $0.00 \%$ & 50 & -0.131 & $100.00 \%$ \\
\hline South Africa & 4 & $12.50 \%$ & 28 & $87.50 \%$ & 0 & $0.00 \%$ & 32 & 2.498 & $42.11 \%$ \\
\hline Norway & 4 & $10.26 \%$ & 34 & $87.18 \%$ & 1 & $2.56 \%$ & 39 & 0.400 & $100.00 \%$ \\
\hline Denmark & 5 & $13.89 \%$ & 30 & $83.33 \%$ & 1 & $2.78 \%$ & 36 & 0.895 & $100.00 \%$ \\
\hline Japan & 3 & $9.09 \%$ & 27 & $81.82 \%$ & 3 & $9.09 \%$ & 33 & 0.106 & $100.00 \%$ \\
\hline Greece & 7 & $14.58 \%$ & 39 & $81.25 \%$ & 2 & $4.17 \%$ & 48 & 0.477 & $97.92 \%$ \\
\hline Sweden & 10 & $18.52 \%$ & 41 & $75.93 \%$ & 3 & $5.56 \%$ & 54 & -0.154 & $100.00 \%$ \\
\hline Finland & 22 & $33.85 \%$ & 43 & $66.15 \%$ & 0 & $0.00 \%$ & 65 & 0.530 & $100.00 \%$ \\
\hline Portugal & 16 & $33.33 \%$ & 30 & $62.50 \%$ & 2 & $4.17 \%$ & 48 & -0.446 & $100.00 \%$ \\
\hline Belgium & 12 & $19.67 \%$ & 38 & $62.30 \%$ & 11 & $18.03 \%$ & 61 & -0.043 & $100.00 \%$ \\
\hline
\end{tabular}


Table 7: Relation Between Lawyers and Sovereign Ratings, 1946-2012

\begin{tabular}{|c|c|c|c|c|c|c|c|c|c|c|c|c|c|c|c|}
\hline & \multicolumn{5}{|c|}{ All jurisdictions } & \multicolumn{5}{|c|}{ New York Law } & \multicolumn{5}{|c|}{ English Law } \\
\hline & \multicolumn{2}{|c|}{ Non Investment } & \multicolumn{2}{|c|}{ Investment grade } & \multirow[t]{2}{*}{ Total } & \multicolumn{2}{|c|}{ Non Investment } & \multicolumn{2}{|c|}{ Investment grade } & \multirow[t]{2}{*}{ Total } & \multicolumn{2}{|c|}{ Non Investment } & \multicolumn{2}{|c|}{ Investment grade } & \multirow[t]{2}{*}{ Tota } \\
\hline & Number & $\%$ total & Number & $\%$ total & & Numbe & $\%$ total & Number & $\%$ total & & Number & $\%$ total & Number & $\%$ total & \\
\hline \multicolumn{16}{|c|}{ Issuer Counsel } \\
\hline Others & 345 & $33.40 \%$ & 688 & $66.60 \%$ & 1,033 & 206 & $58.86 \%$ & 144 & $41.14 \%$ & 350 & 84 & $18.54 \%$ & 369 & $81.46 \%$ & 453 \\
\hline Cleary Gottlieb & 127 & $66.84 \%$ & 63 & $33.16 \%$ & 190 & 95 & $64.19 \%$ & 53 & $35.81 \%$ & 148 & 27 & $72.97 \%$ & 10 & $27.03 \%$ & 37 \\
\hline Total & 472 & $38.59 \%$ & 751 & $61.41 \%$ & 1,223 & 301 & $60.44 \%$ & 197 & $39.56 \%$ & 498 & 111 & $22.65 \%$ & 379 & $77.35 \%$ & 490 \\
\hline \multicolumn{16}{|c|}{ Underwriters Counsel } \\
\hline Others & 376 & $35.67 \%$ & 678 & $64.33 \%$ & 1,054 & 205 & $60.47 \%$ & 134 & $39.53 \%$ & 339 & 111 & $22.79 \%$ & 376 & $77.21 \%$ & 487 \\
\hline Sullivan\& Cromwell & 96 & $56.80 \%$ & 73 & $43.20 \%$ & 169 & 96 & $60.38 \%$ & 63 & $39.62 \%$ & 159 & 0 & $0.00 \%$ & 3 & $100.0 \%$ & 3 \\
\hline Total & 472 & $38.59 \%$ & 751 & $61.41 \%$ & 1,223 & 301 & $60.44 \%$ & 197 & $39.56 \%$ & 498 & 111 & $22.65 \%$ & 379 & $77.35 \%$ & 490 \\
\hline
\end{tabular}




\section{Table 8}

\section{Cost of Debt}

OLS results. Dependent variable is the Spread between the interest rate of the bond and the rate on a U.S. Treasury bond with the same maturity. Ratings are taken from S\&P with the pluses and minuses being combined with the lettered ratings. BBB is the holdout category. Ln(amount) is the log of the size of the issue. Maturity is stated in number of years. Number of Banks is the number of banks participating in the offer. Cleary is equal to one if that firm is the Issuer Counsel. Top Underwriter is equal to one if Sullivan \& Cromwell (US) or Linklaters (English) is the law firm working with the underwriter. Issuer Counsel and No Lawyers are dummy variables equal to 1 if there are two and zero law firms involved, respectively. All models include fixed time effects. Standard errors are reported in parentheses and are clustered at the country level. $* * *$ indicates significance at the $1 \%$ level, $* *$ indicates significance at the $5 \%$ level and $*$ indicates significance at the $10 \%$ level.

\begin{tabular}{|c|c|c|c|c|c|c|c|c|c|}
\hline & \multicolumn{3}{|c|}{ All Sample } & \multicolumn{3}{|c|}{ NY Law } & \multicolumn{3}{|c|}{ English Law } \\
\hline & (1) & (2) & (3) & (4) & (5) & (6) & (7) & (8) & (9) \\
\hline AAA & $\begin{array}{c}-1.599 * * * \\
(0.535)\end{array}$ & & & $\begin{array}{c}-1.476^{* * * *} \\
(0.542)\end{array}$ & & & $\begin{array}{c}-2.828^{* *} \\
(1.228)\end{array}$ & & \\
\hline AA & $\begin{array}{c}-1.319 * * * \\
(0.410)\end{array}$ & & & $\begin{array}{c}-1.427 * * * \\
(0.424)\end{array}$ & & & $\begin{array}{c}-1.504^{* *} \\
(0.708)\end{array}$ & & \\
\hline A & $\begin{array}{l}-0.588 \\
(0.394)\end{array}$ & & & $\begin{array}{l}-0.350 \\
(0.413)\end{array}$ & & & $\begin{array}{l}-0.902 \\
(0.667)\end{array}$ & & \\
\hline $\mathrm{BB}$ & $\begin{array}{c}1.982 * * * \\
(0.528)\end{array}$ & & & $\begin{array}{c}1.381 * * * \\
(0.394)\end{array}$ & & & $\begin{array}{c}3.240 * * \\
(1.466)\end{array}$ & & \\
\hline B & $\begin{array}{c}2.719 * * * \\
(0.335)\end{array}$ & & & $\begin{array}{c}2.688 * * * \\
(0.401)\end{array}$ & & & $\begin{array}{c}3.268 * * * \\
(0.747)\end{array}$ & & \\
\hline Ln(amount) & $\begin{array}{c}-0.0792 \\
(0.0768)\end{array}$ & $\begin{array}{c}-0.317 * * \\
(0.126)\end{array}$ & & $\begin{array}{c}0.0818 \\
(0.0935)\end{array}$ & $\begin{array}{l}-0.0990 \\
(0.172)\end{array}$ & & $\begin{array}{l}-0.223 \\
(0.174)\end{array}$ & $\begin{array}{c}-0.650 * * \\
(0.297)\end{array}$ & \\
\hline Maturity & $\begin{array}{c}-0.00943 \\
(0.0130)\end{array}$ & $\begin{array}{c}0.00686 \\
(0.0141)\end{array}$ & & $\begin{array}{c}-0.0180 * * \\
(0.00799)\end{array}$ & $\begin{array}{c}-0.0135 \\
(0.0138)\end{array}$ & & $\begin{array}{c}-0.0372 \\
(0.0450)\end{array}$ & $\begin{array}{l}-0.0484 \\
(0.0437)\end{array}$ & \\
\hline Number of banks & $\begin{array}{l}0.00774 \\
(0.0368)\end{array}$ & $\begin{array}{l}-0.00201 \\
(0.0305)\end{array}$ & & $\begin{array}{c}-0.0574 * * * \\
(0.0211)\end{array}$ & $\begin{array}{l}-0.0622 \\
(0.0414)\end{array}$ & & $\begin{array}{c}0.0962 \\
(0.0955)\end{array}$ & $\begin{array}{l}0.0845 \\
(0.107)\end{array}$ & \\
\hline Cleary & $\begin{array}{c}0.180 \\
(0.288)\end{array}$ & $\begin{array}{l}0.0297 \\
(0.382)\end{array}$ & & $\begin{array}{l}-0.0480 \\
(0.313)\end{array}$ & $\begin{array}{l}-0.319 \\
(0.455)\end{array}$ & & $\begin{array}{l}-0.776 \\
(0.890)\end{array}$ & $\begin{array}{c}0.177 \\
(1.190)\end{array}$ & \\
\hline Top Underwriter & $\begin{array}{c}-0.0168 \\
(0.193)\end{array}$ & $\begin{array}{c}0.340 \\
(0.243)\end{array}$ & & $\begin{array}{l}0.0600 \\
(0.175)\end{array}$ & $\begin{array}{c}0.321 \\
(0.209)\end{array}$ & & $\begin{array}{c}0.359 \\
(0.360)\end{array}$ & $\begin{array}{c}-0.0682 \\
(0.534)\end{array}$ & \\
\hline Issuer Counsel & $\begin{array}{l}-0.146 \\
(0.487)\end{array}$ & $\begin{array}{c}1.282 * * * \\
(0.434)\end{array}$ & $\begin{array}{c}1.494 * * * \\
(0.414)\end{array}$ & $\begin{array}{c}0.421 \\
(0.352)\end{array}$ & $\begin{array}{c}2.025 * * * \\
(0.662)\end{array}$ & $\begin{array}{c}2.089 * * * \\
(0.734)\end{array}$ & $\begin{array}{l}-0.571 \\
(0.827)\end{array}$ & $\begin{array}{c}1.088 \\
(0.790)\end{array}$ & $\begin{array}{c}1.145^{*} \\
(0.590)\end{array}$ \\
\hline No Lawyers & $\begin{array}{l}-0.955 \\
(0.748)\end{array}$ & $\begin{array}{l}-0.507 \\
(0.547)\end{array}$ & $\begin{array}{c}-0.0449 \\
(0.333)\end{array}$ & & & $\begin{array}{c}-3.175^{* * *} \\
(0.145)\end{array}$ & $\begin{array}{l}-0.383 \\
(1.282)\end{array}$ & $\begin{array}{c}0.578 \\
(1.630)\end{array}$ & $\begin{array}{c}0.565 \\
(0.719)\end{array}$ \\
\hline Constant & $\begin{array}{c}7.343^{* * * *} \\
(1.204)\end{array}$ & $\begin{array}{c}5.663 * * * \\
(1.060)\end{array}$ & $\begin{array}{c}7.052 * * * \\
(0.604)\end{array}$ & $\begin{array}{c}7.831 * * * \\
(0.622)\end{array}$ & $\begin{array}{c}3.103 * * * \\
(0.989)\end{array}$ & $\begin{array}{c}2.896^{* * * *} \\
(0.461)\end{array}$ & $\begin{array}{l}-1.111 \\
(3.028)\end{array}$ & $\begin{array}{l}-0.782 \\
(2.644)\end{array}$ & $\begin{array}{c}-1.195 * * \\
(0.590)\end{array}$ \\
\hline Observations & 791 & 857 & 1,072 & 355 & 371 & 445 & 298 & 328 & 409 \\
\hline R-squared & 0.329 & 0.208 & 0.265 & 0.627 & 0.411 & 0.446 & 0.263 & 0.141 & 0.151 \\
\hline
\end{tabular}


Figure 1: Confederate Cotton Bond

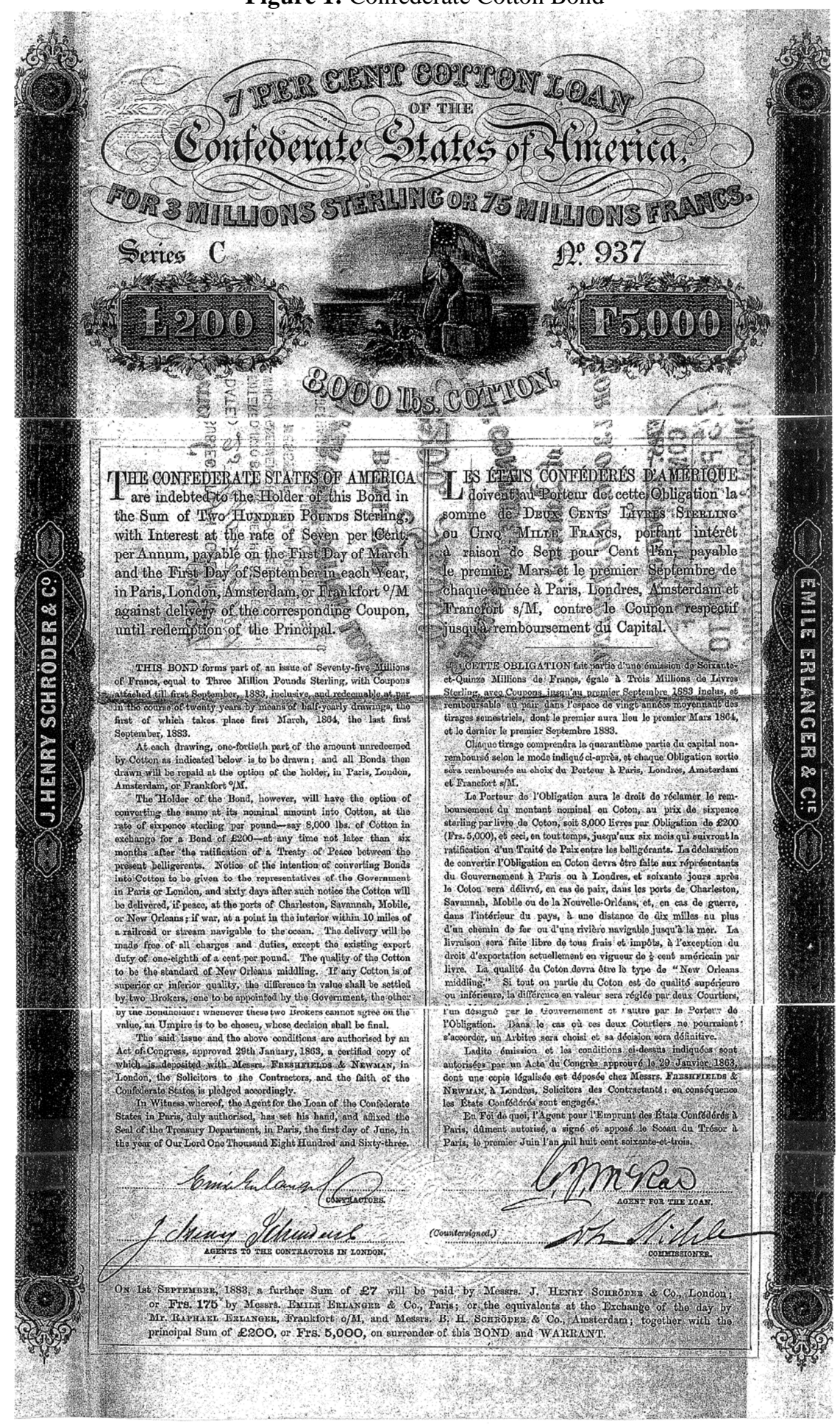


Figure 2: Number of Issuances by Jurisdiction post-World War II

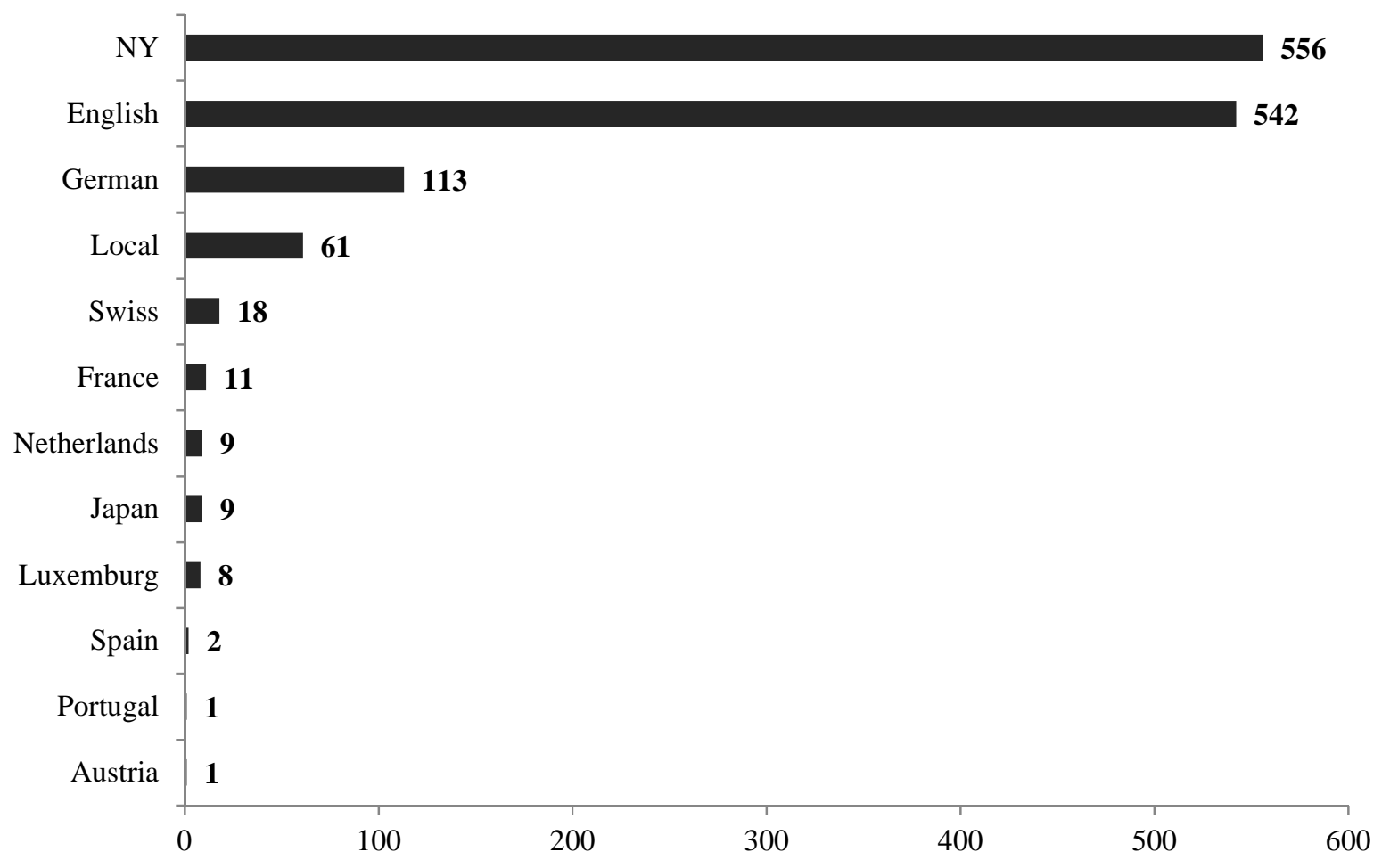

Figure 3: Issuances by Jurisdiction and Number of Lawyers post-World War II

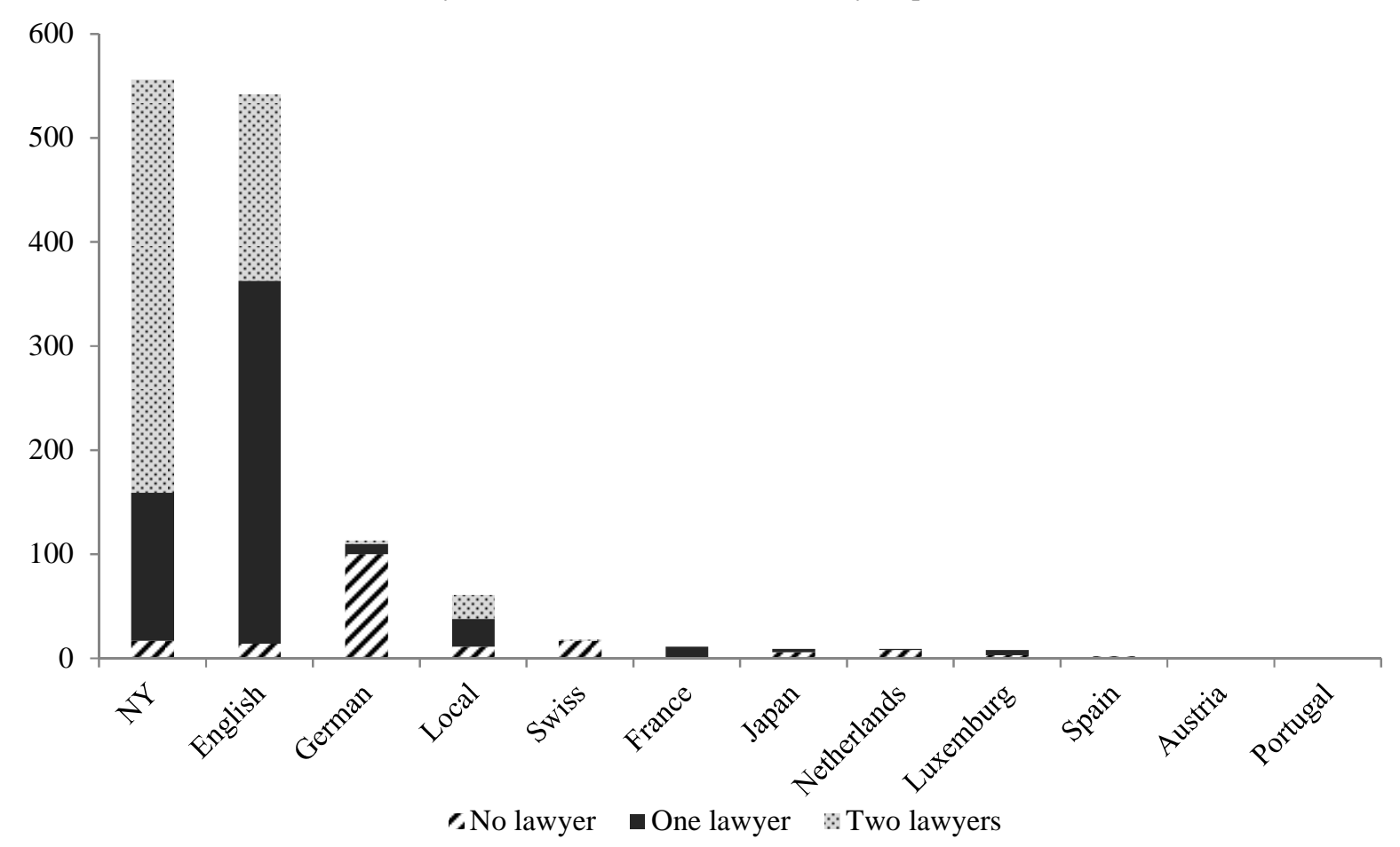


Figure 4: Investment Bank Long Term Relationship with Issuer, 1826-1945

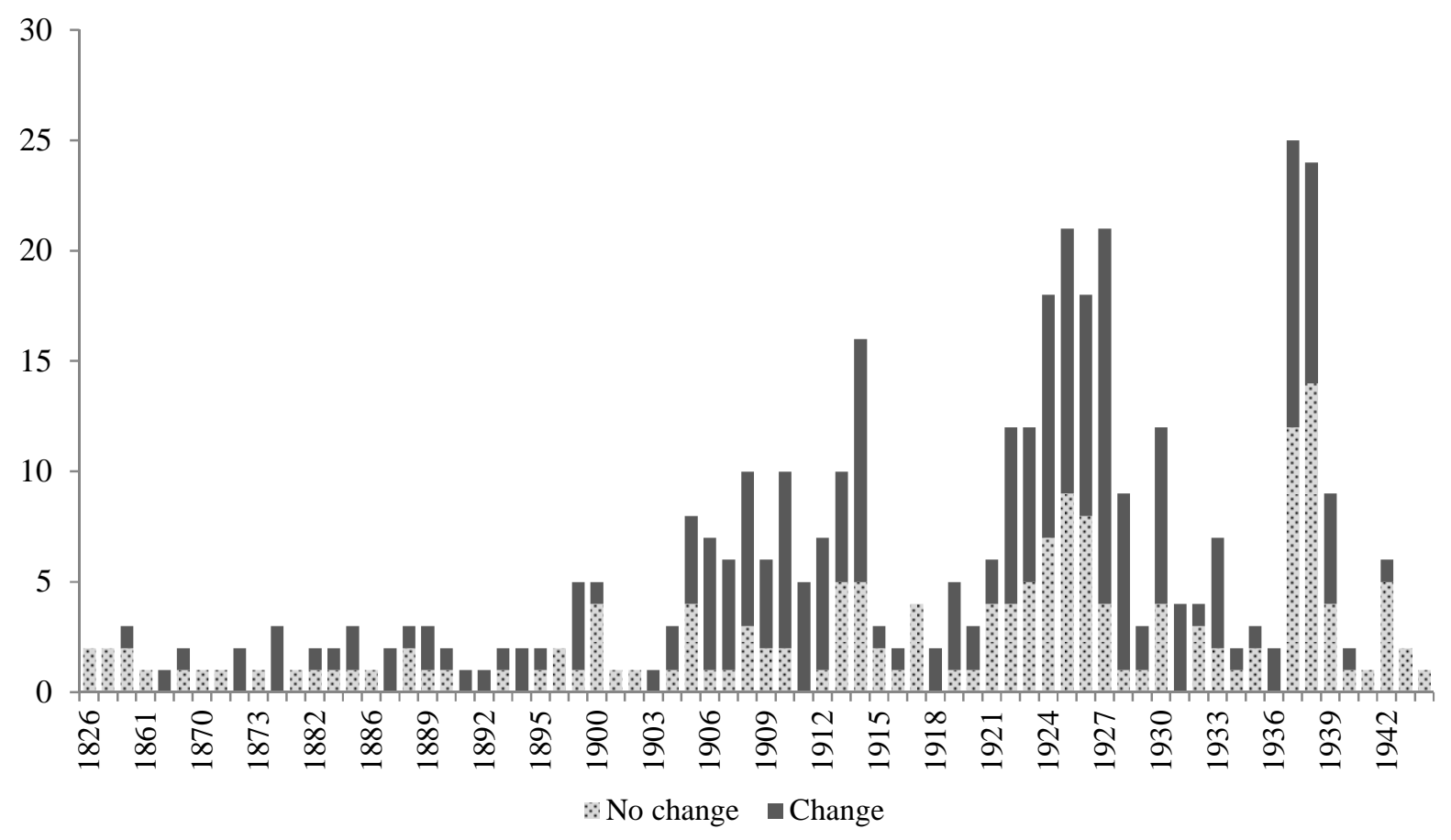

Figure 5: Investment Bank Long Term Relationship with Issuer, 1946-2012

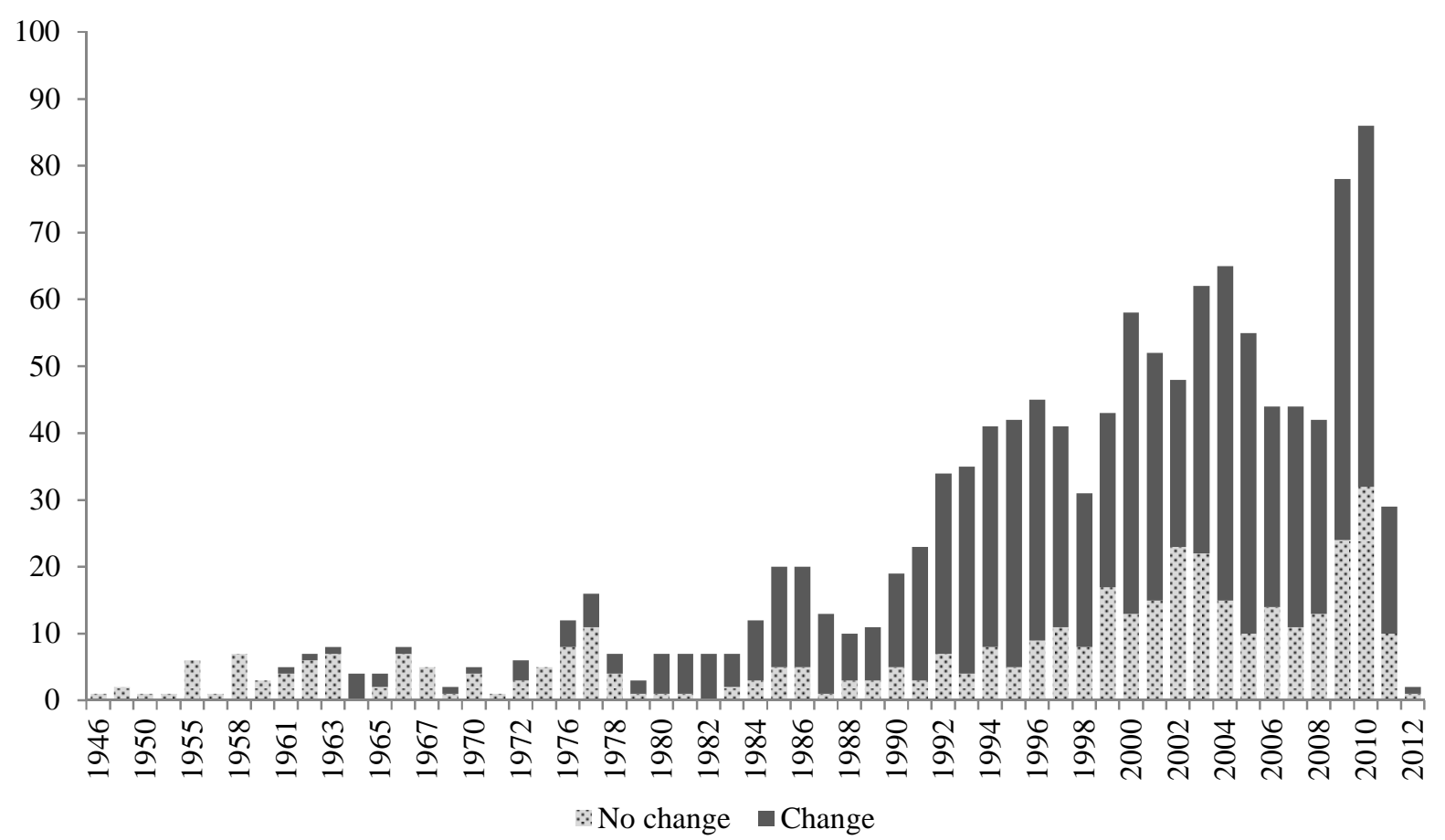


Figure 6: Investment Bank Long Term relationship with Issuers; New York Law Bonds, 1946-2012

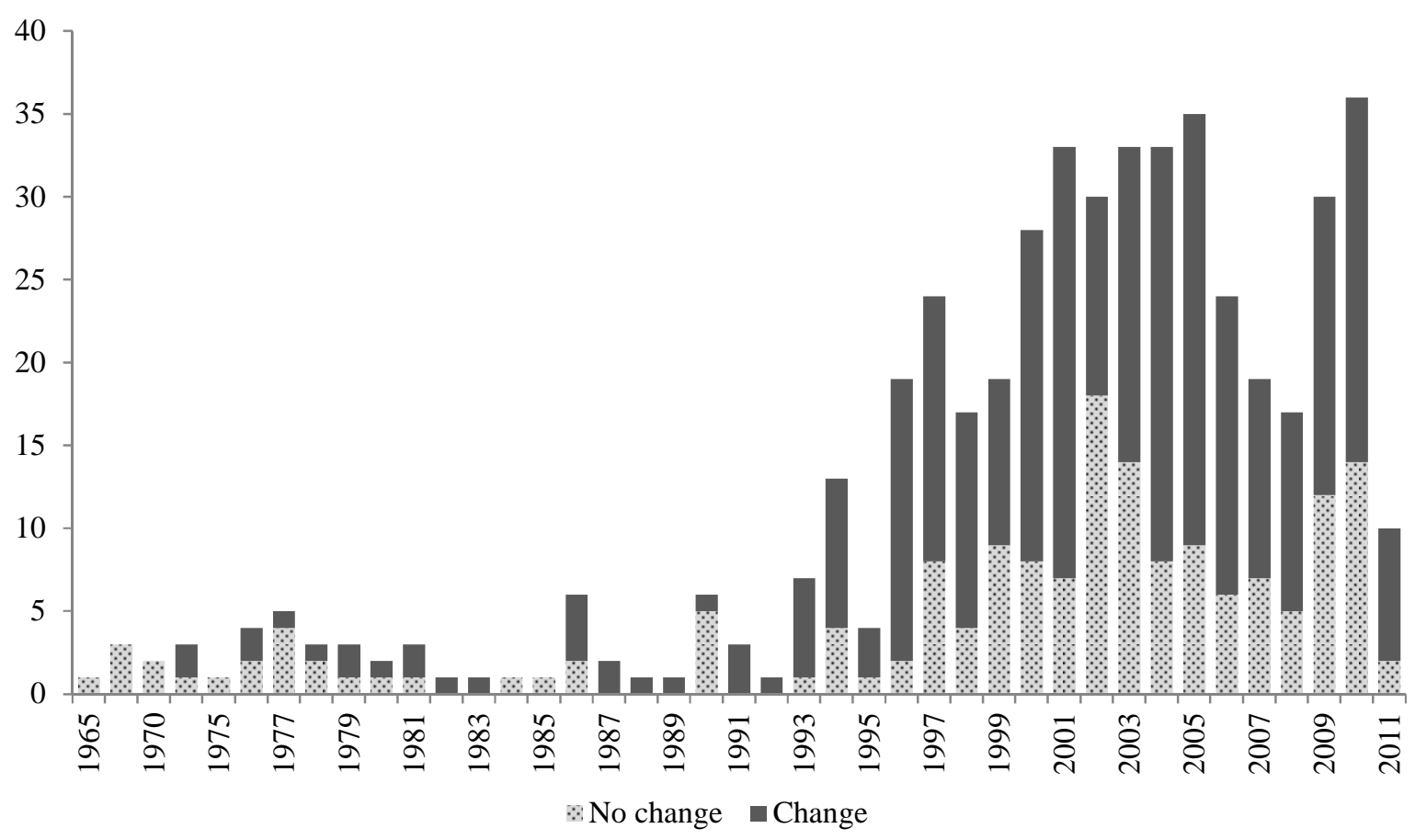

Figure 7: Investment Bank Long Term Relationship with Issuers; English Law Bonds, 1946-2012

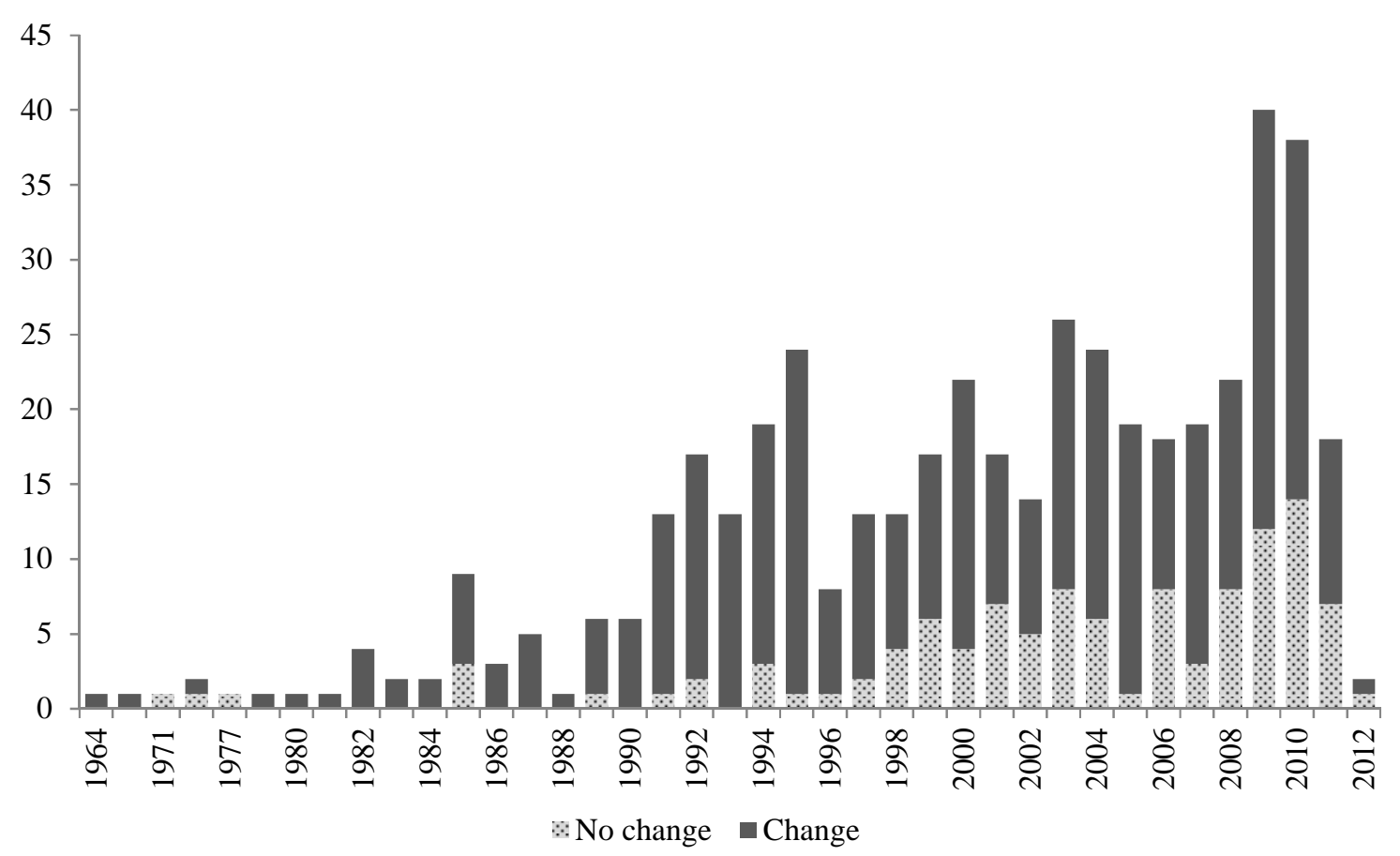


Figure 8: Issuer Counsel Long Term Relationship with Issuers, 1946-2012

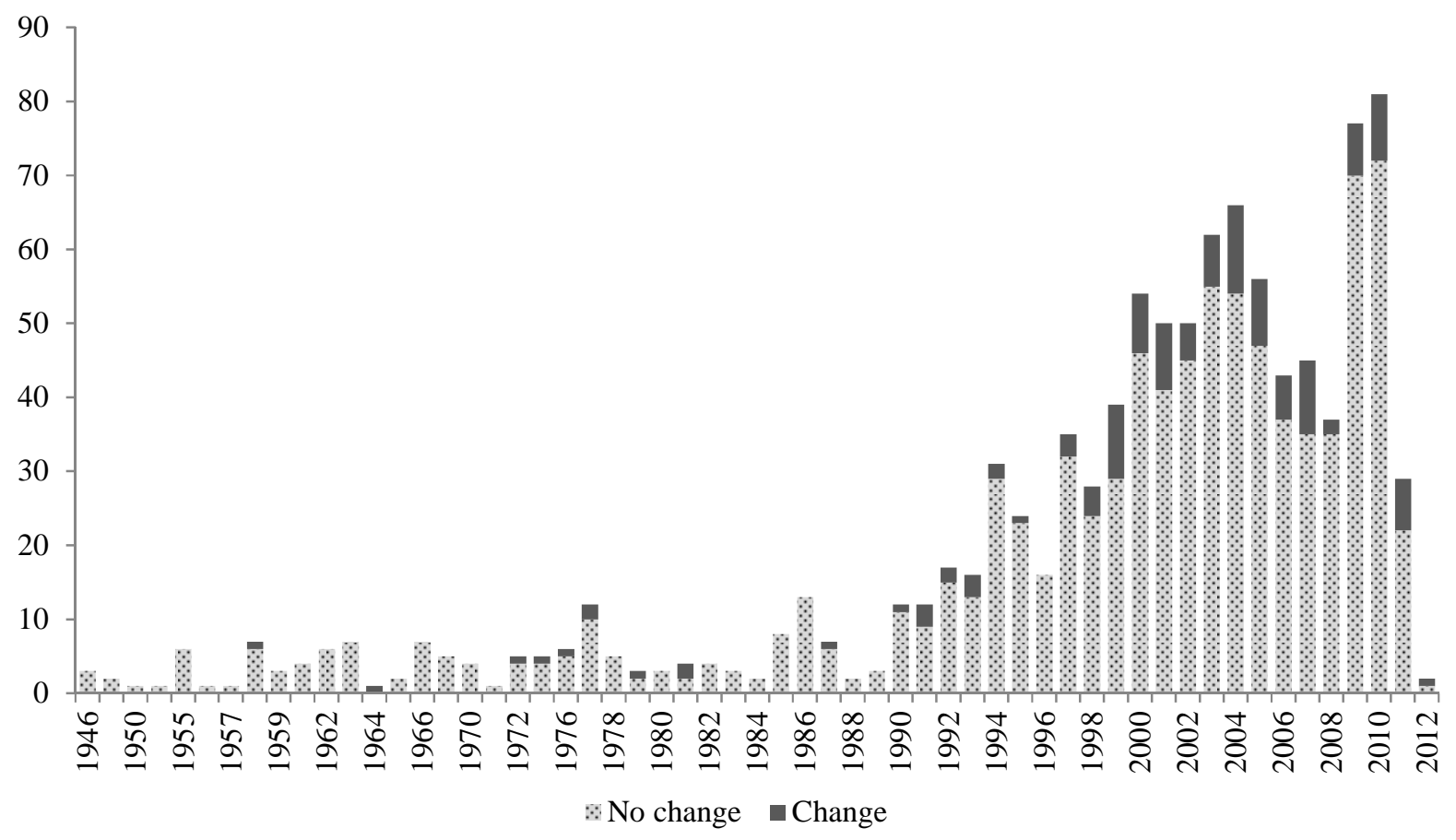

Figure 9: Investment Bank Counsel Long Term Relationship with Issuers, 1946-2012

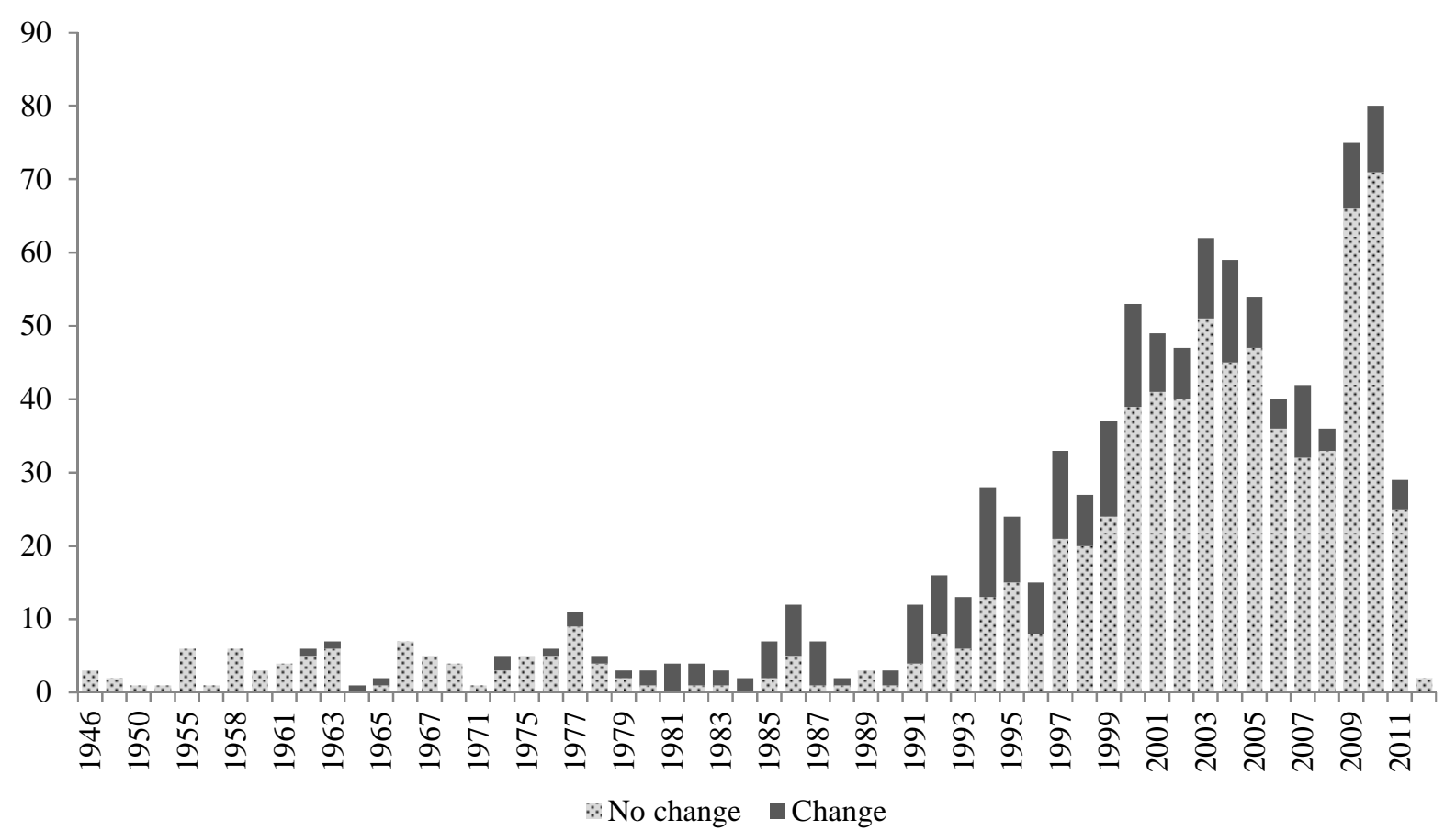


Figure 10: Number of Law Firms; All Issuances 1946 - 2012

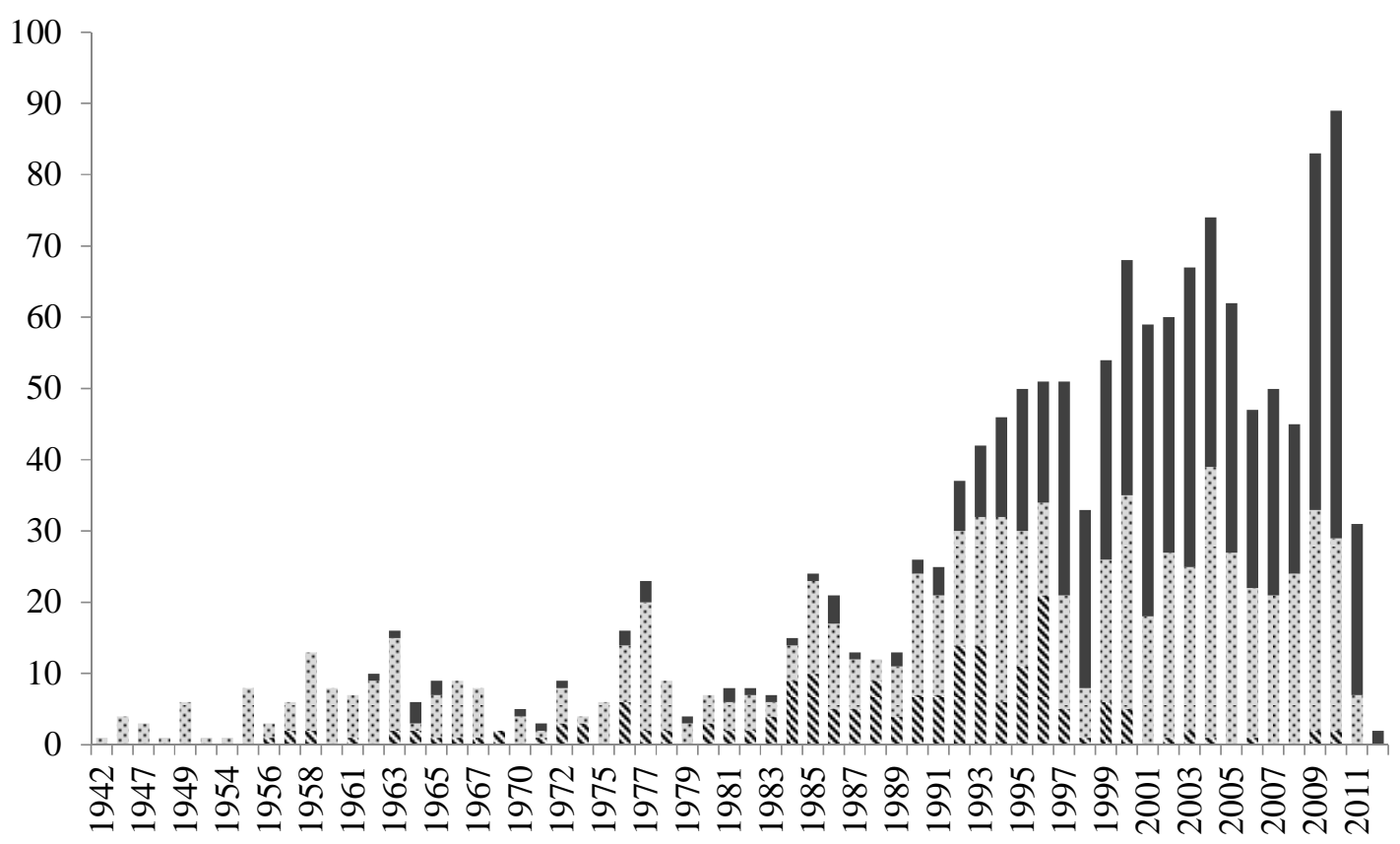

s No lawyer $\quad$ One lawyer $\quad$ Two lawyers

Figure 11: Number of Lawyers; New York Law Issuances, 1946 - 2012

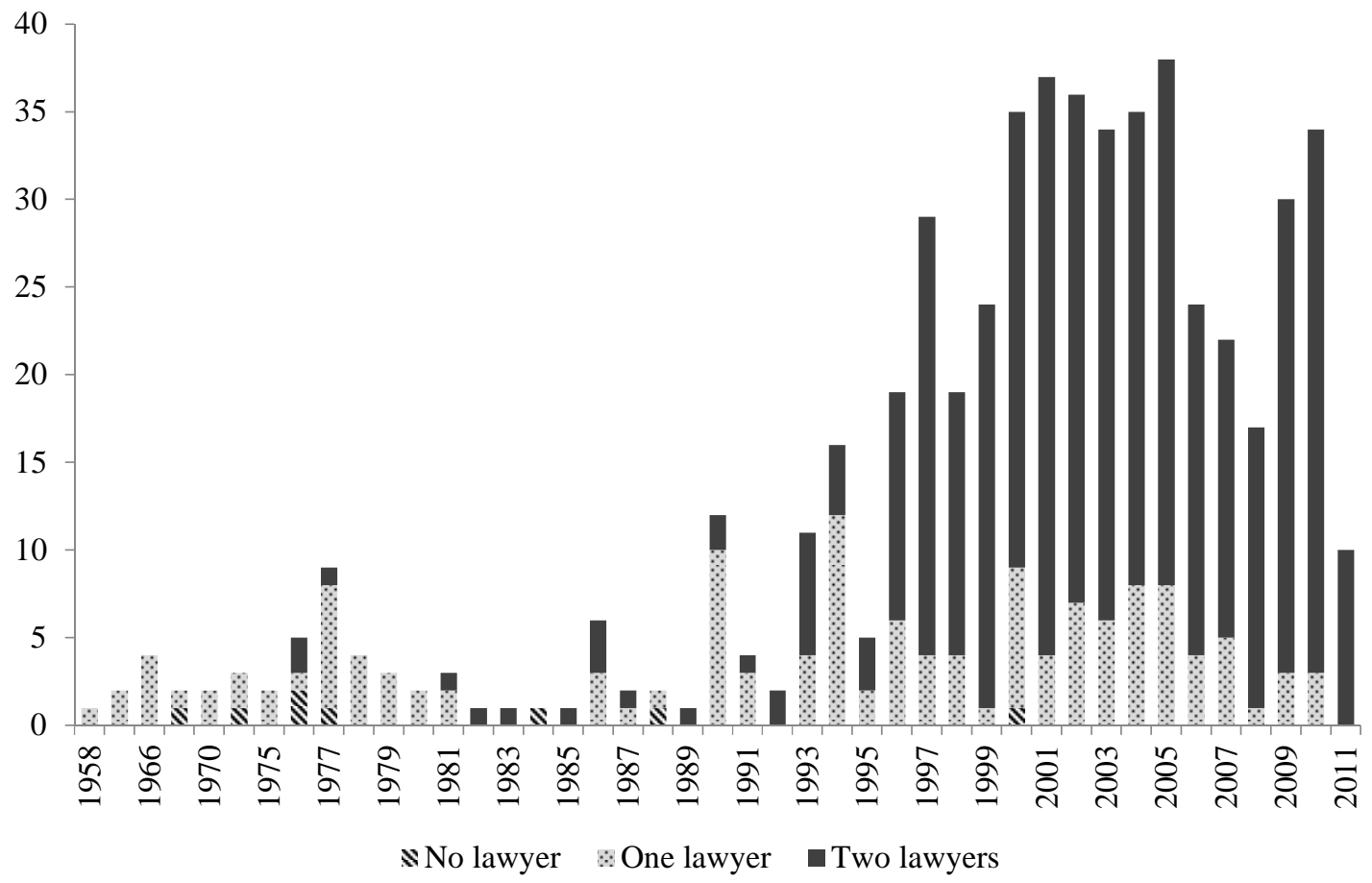


Figure 12: Number of Law Firms; English Law Issuances, 1946 - 2012

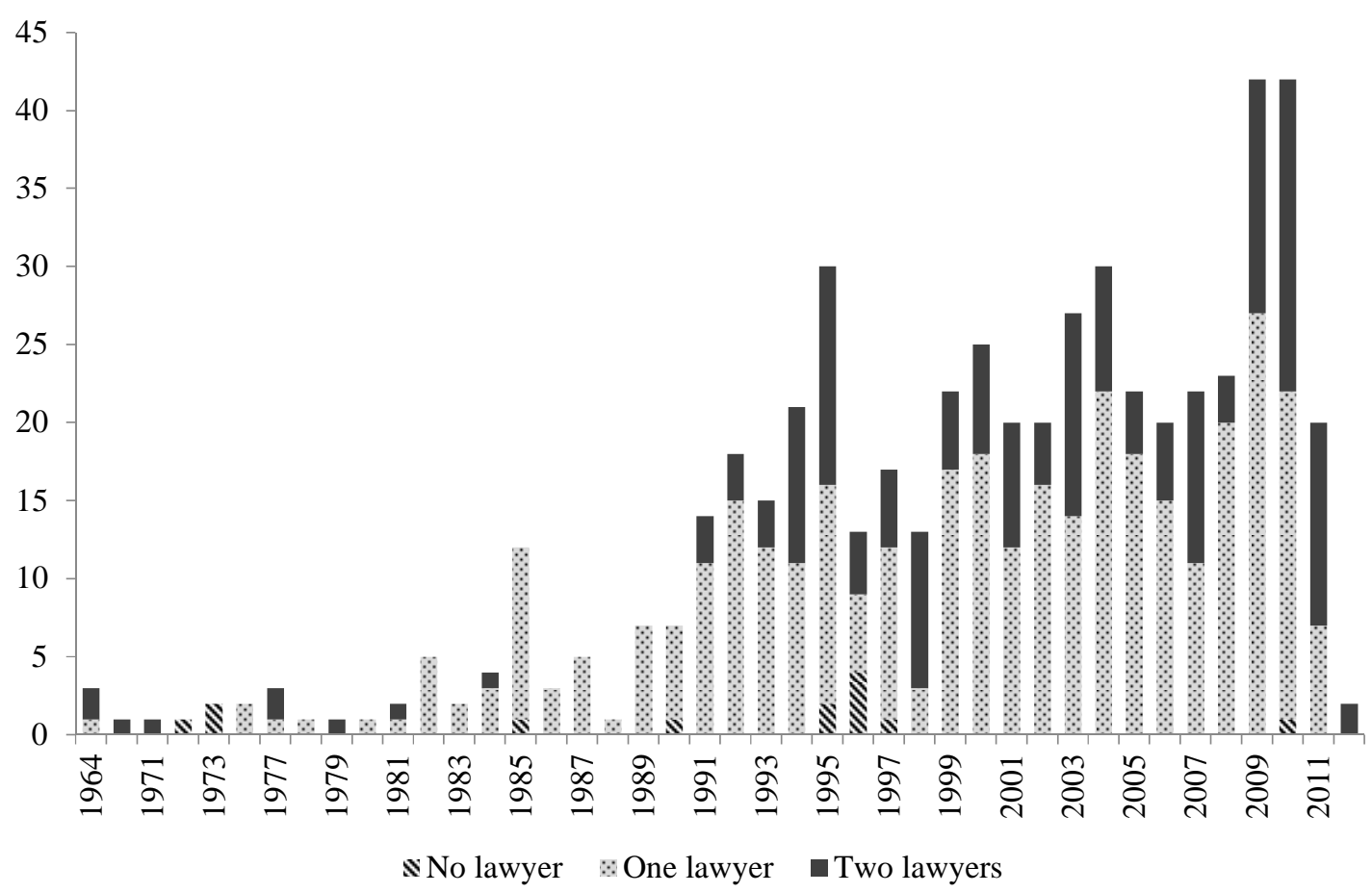

